This is the peer reviewed version of the following article: Milan, D. (2017). Controls on spatial and temporal variations in sand delivery to salmonid spawning riffles. Hydrological Processes, 31(12), (2179-2195). doi:10.1002/hyp.11172. ISSN 0885-6087, which has been published in final form at https://doi.org/10.1002/hyp.11172. This article may be used for non-commercial purposes in accordance With Wiley Terms and Conditions for self-archiving.

\title{
Controls on spatial and temporal variations in sand delivery to salmonid spawning riffles
}

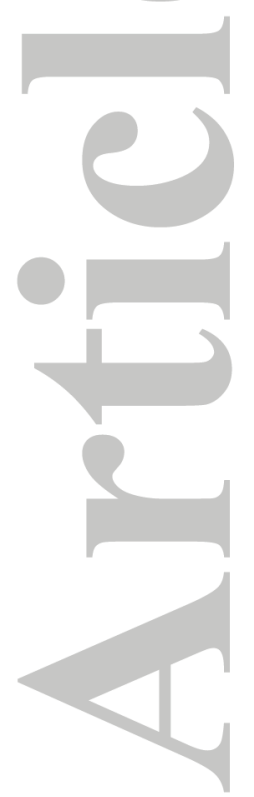

David Milan

School of Environmental Sciences, University of Hull, Cottingham Road, Hull, HU6 7RX,

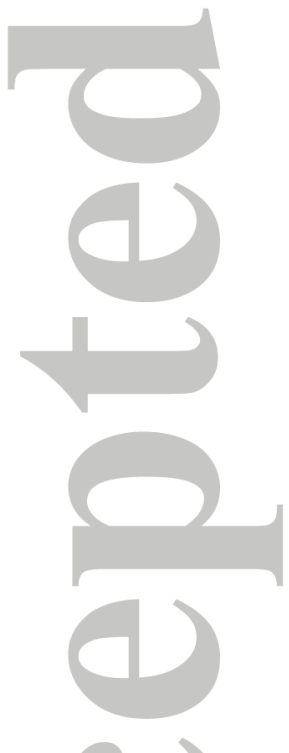

UK

d.milan@hull.ac.uk

Keywords: fine-grained sediment, brown trout embryos, hydraulics, siltation, bedload, relative roughness

This article has been accepted for publication and undergone full peer review but has not been through the copyediting, typesetting, pagination and proofreading process which may lead to differences between this version and the Version of Record. Please cite this article as doi: 10.1002/hyp.11172 


\section{ABSTRACT}

Fine sediment infiltration into gravel interstices is known to be detrimental to incubating salmonid embryos. Infiltration into spawning riffles can show large spatial variations at the scale of a morphological unit and over time, with significant implications for embryo survival. Furthermore some process-based infiltration studies, and incubation-to-emergence models assume that fines are delivered to redds via suspension rather than bedload. This process-based twelve-month study examined spatial patterns of predominantly sand infiltration into gravels in an upland trout stream, using infiltration baskets. An assessment of Rouse numbers for infiltrated sand indicated that it was transported predominantly as bedload at flow peaks. Clear temporal and spatial patterns existed; with highest rates of infiltration strongly associated with higher discharges $\left(r^{2}=0.7, p<0.05\right)$. Seasonal variations in the delivery of different grain-sizes were also a feature; with enhanced contributions of $0.5-2 \mathrm{~mm}$ sediment, during elevated winter flows, and 0.125-0.5 mm sediment during spring and summer; the latter potentially harmful to the later stages of embryo incubation. Clear spatial patterns were also evident across riffles; with highest rates of infiltration tending to occur in areas of lower relative roughness; the areas competent to transport sand for longer periods. Incubation-to-emergence models should take into consideration spatial patterns of fine sediment dynamics at the pool-riffle scale, to improve prediction. 


\section{INTRODUCTION}

The detrimental biological impacts of fine-grained sediment $(<2 \mathrm{~mm})$ infiltration into gravel interstitial voids are well documented (Wood and Armitage, 1997), where particular emphasis has been placed upon the impacts to salmonid embryos (Soulsby et al., 2001; Jensen et al., 2009; Kemp et al., 2011), and macroinvertebrate communities (Extence et al., 2013; Jones et al., 2011; Mathers et al., 2014). A variety of metrics have been used to describe fine sediment, ranging from clay $(<0.004 \mathrm{~mm})$ through to sands and granules up to $12.7 \mathrm{~mm}$ (Tappel and Bjornn, 1983; Greig et al., 2005). Different size classes are known to impact different stages of the embryonic part of the salmonid life-cycle. Ingress of silts and fine sands can block interstitial flow pathways, reducing permeability and intragravel velocity, starving embryos of dissolved oxygen, and failing to remove metabolic waste products; effectively poisoning the embryos (Chapman, 1988; Acornley and Sear, 1999; Greig et al., 2005; Kondolf et al., 2008). As finer grades $(<0.063 \mathrm{~mm})$ are known to preferentially infiltrate deeper through gravel voids (Einstein, 1968), this effect is most pronounced in the early stages of embryo survival when the embryos are immobile and are positioned deeper in the redd. In addition to reduced permeability and intragravel velocity, Greig et al. (2005a,b) have shown that clay-sized sediment can reduce dissolved oxygen diffusion across embryo membranes. In addition to the physical effects of the interstitial fine sediment, the organic component has also been shown to reduce dissolved oxygen availability to embryos through its decomposition (Greig et al., 2005a,b, Sear et al., 2014), and block interstitial pathways through biofilm formation (Petticrew and Arocena, 2003). The later mobile stage of embryonic development, when the embryo develops into an alevin, is susceptible to coarser sands and granules, that have a tendency to block the near surface voids (Beschta and Jackson, 1979); creating a physical blockage to alevin escape from the redd.

Several studies have developed models to predict spawning habitat quality, some of which rely on developing predictive relationships between fine sediment concentrations $(<2 \mathrm{~mm}$, or $<1 \mathrm{~mm}$; Jensen et al., 2009; Julien and Bergeron, 2006; Heywood and Walling, 2007; Kemp et al., 2011, Sear et al., 2014) and embryo survival. However, survival can also be predicted from infiltration rates (Lisle and Lewis, 1992). Improved understanding of the controls on infiltration of interstitial fines may potentially offer improvements to such models. 


\section{Fine sediment management issues}

Fine sediment delivery to salmonid spawning habitat is known to be influenced by catchment-scale processes and management. For example, a number of studies in the US dating back to the 1960s have shown the deleterious impacts of timber harvesting upon increased fine sediment loadings in fish spawning gravels (Hall and Lantz, 1969; Duncan and Ward, 1985). In the UK fine sediments have been recognized as a contaminant due to their association with heavy metals (Petts et al., 1989), nutrients such as phosphorous, pesticides and persistant organic pollutants (Walling and Collins, 2016). Changes in gravel quality (Kondolf et al., 2008) have also been associated with flow regulation (Petts, 1984; Sear, 1992; Milan, 1994), and low flows (Milan and Petts, 1998). Many upland catchments in the UK are dominated by moorland-peatland areas, often with modified drainage (grips). Gripping has the effect of lowering the water table, has been shown to increase flood peaks (Gunn and Walker, 2000), and can also be dominant sources of fine sediment (Holden et al., 2007). Rotational patch burning, can also increase sediment and organic matter delivery to streams (Tallis, 1987), with consequences for instream biota (Brown et al., 2014).

Furthermore, over the last 20 years in the UK there have been particular concerns regarding agricultural diffuse pollution, related to intensification and changes in farming practice (Theurer et al., 1998; Collins and Anthony, 2008; Stopps et al., 2012). The problem of fine sediment pollution in river catchments in Europe is currently being addressed through the Water Framework and Freshwater Fish and Habitats Directives (European Parliament, 2000).

\section{Infiltration controls}

Infiltration of fines into gravel-beds has been demonstrated by a number of laboratory (Einstein, 1968; Beschta and Jackson, 1979; Carling, 1984; Schälchli, 1992; 1995; Allan and Frostick, 1999) and field studies (Frostick et al., 1984; Sear, 1993; Acornley and Sear, 1999; Zimmerman and Lapointe, 2005; Mather and Wood, 2016). Two different mechanisms of infiltration have been reported, governed by the size of the infiltrating fines and the size and shape of the receiving gravel framework voids (Meehan and Swanston, 1977; Frostick et al., 1984), and hydraulic conditions (Beschta and Jackson, 1979; Allan and Frostick, 1999). Over stable openwork gravel it appears that finer grades $(<0.063 \mathrm{~mm})$ infiltrate deeper and fill voids the base upwards (Einstein, 1968). Conversely, coarser grades (sands and fine gravel) may form near-surface seals, bridging the framework voids and preventing further ingress (Beschta and Jackson, 1979). 
A number of flume-based investigations have drawn links between hydraulics and infiltration dynamics (Beschta and Jackson, 1979; Schälchli, 1992; 1995; Allan and Frostick, 1999). Over stable beds, Beschta and Jackson (1979) found greater depths of fine sediment intrusion at higher shear stresses $\left(\tau_{o}\right)$. At $\tau_{o}$ around the threshold for gravel framework mobilisation, dilation of framework particles can occur; opening up previously blocked void spaces. Dilation causes a change in pressure differentials between the void spaces and induces the 'Venturi' effect, encouraging deeper penetration of fines (Allan and Frostick, 1999). At even greater $\tau_{o}$, total flushing or desiltation of interstitial framework voids may occur (Schächli 1992; 1995).

\section{Spatial patterns of infiltration}

A number of field studies have also shown spatial variability in infiltration across morphological units (Table 1), and have linked this to velocity patterns. Knowledge of the spatial patterns of fine sediment infiltration are important because salmonids have been reported either to favour riffle heads or tails for spawning sites, as these areas have been reported to have enhanced downwelling or upwelling flow respectively (Briggs, 1953; Hoopes, 1972, Hunter, 1973; Crisp and Carling, 1989; Tonina and Buffington, 2009). Carling and McCahon's (1987) experiments on the upland Great Eggleshope Beck, UK, demonstrated that the infiltration rate of fines increased linearly from the outside of a river bend toward the inside. Maturana et al's (2014) modelling study also suggests that fine sediment can be steered away from pools; tending to infiltrate point bars and shielding downstream riffle spawning habitat from sedimentation. Variations in fine sediment infiltration between pool-riffle units has also been documented (Carling and McCahon, 1987); for a $10 \%$ increment in stream width, the infiltration rate increased by $0.017 \mathrm{kgm}^{-2} \mathrm{day}^{-}$ ${ }^{1}$ in the pool and $0.015 \mathrm{kgm}^{-2} \mathrm{day}^{-1}$ over the riffle. The $2-4 \mathrm{~mm}$ fraction was found to show enhanced infiltration rates in high velocity zones in the pool and a number of other high velocity threads across shallower areas. Welton (1980) has also shown spatial variation for Tadnoll Brook, UK, a lowland chalk stream, with $5 \mathrm{kgm}^{-2}$ day $^{-1}$ deposited along the thalweg and up to $70 \mathrm{kgm}^{-2} \mathrm{day}^{-1}$ deposited along the channel margins. Fines deposited in this lowenergy stream were probably dominated by grades transported in suspension rather than bedload, showing enhanced deposition along the low velocity channel margins. 


\section{Study goals}

This study seeks to further quantify the effects of hydraulics and local morphology upon fine sediment infiltration dynamics, with particular emphasis given to the sand load. Improved information is needed concerning the physical controls on infiltration rate, to improve the predictive capabilities of salmonid embryo incubation-to-emergence models. Furthermore, knowledge of hydraulic controls on fine sediment infiltration may aid environmental flow design in regulated rivers (Kondolf and Wilcock, 1996), and a better understanding of the morphological controls on infiltration may assist future design of spawning riffles in river restoration projects (Pasternack and Brown, 2013; Schwartz et al., 2015). This study aims to identify

a) spatial variations in the quantity and grain-size of sand infiltrating salmonid spawning habitat over a full hydrological year,

b) the effect of local hydraulics and morphology on fine sediment infiltration.

\section{STUDY SITE}

The study was conducted on a $250 \mathrm{~m}$ reach of the River Rede, a headwater tributary to the river North Tyne in Northumberland, UK (Figure 1). The River Rede at this location, is unregulated and provides habitat for brown trout (Salmo trutta L.), and supports populations of two species that are of international conservation significance; brook lamprey (Lampetra planeri L.) and bullhead (Cottus Gobbio L.). Both species are listed under Annex II of the Habitats and Species Directive (92/43/EEC). Sea trout (migratory form of Salmo trutta L.) and Atlantic salmon (Salmo salar L.) are supported downstream of the study site, in the regulated Rede below Catcleugh reservoir, however their migration to what would have been their natural spawning sites is impeded. The study site has a Strahler stream order of 4 and is a single-thread, sinuous gravel-bed channel with well developed pool-riffle morphology (Milan et al., 2001; Heritage and Milan, 2004). Brown trout select riffles for spawning on the Rede, with redds tending to be located in patches of finer, movable, gravel. Although smallscale redd morphology was evident, there was no evidence of larger-scale changes to bed morphology (sensu Hassan et al., 2008). The Rede drains a moorland catchment of $18 \mathrm{~km}^{2}$ upstream of the site, devoid of trees, with an impermeable geology of Carboniferous sandstones and shales overlain by peat and till. The mean annual runoff is $1026 \mathrm{~mm}$ and the flow regime is flashy. Bankfull discharge recorded at the study reach (GS, Figure 1b), and supported by post-flood trash line observations, is approximately $9 \mathrm{~m}^{3} \mathrm{~s}^{-1}$. Bankfull channel width is between 9 and $18 \mathrm{~m}$ and the average bankfull channel depth is $0.7 \mathrm{~m}$. The mean 
gradient of the bed throughout the reach is $0.006 \mathrm{~m} / \mathrm{m}$. Suspended sediment concentrations are typically below $50 \mathrm{mgl}^{-1}$ for flood peaks (Milan, 2000), low in comparison to other UK rivers (Walling and Webb, 1987). Fine sediments are largely sourced from till at eroding bluffs in slope-channel coupling zones and from remobilized bed material; mainly from point bars (Milan and Large, 2014). Some modification to land drainage is evident in the headwaters, in the form of grips cut into the peat, however their sparse distribution is unlikely to play a significant role in altering catchment hydrology or sediment delivery. In addition, there was no evidence of moorland burning, a common form of upland management, during the period if the investigation. Sheep grazing is the dominant land-use in the catchment upstream of the study site. Results presented in this paper focus upon a single $110 \mathrm{~m}$ length pool-riffle unit towards the head of the reach (Figure 1b, c).

\section{METHODS}

\section{Baseline sediment characteristics}

Surface sediments were sampled using a modified grid-by-number method (Wolman, 1954), whereby the intermediate axis of 450 clasts were sampled from each riffle and 100 clasts from each of the pools. In order to characterise the proportion and grain-size characteristics of $<2 \mathrm{~mm}$ sediment material held within the sub-surface, sediments were sampled using freeze-coring (McNeil and Ahnell, 1960; Petts et al., 1989; Milan, 1996). Freeze-coring has the advantage over other sub-aqueous sediment sampling techniques in that all size fractions can be retrieved in situ, without washout of the finer fractions, and frozen cores also permit variations in vertical structure to be assessed (Thoms, 1992; Milan et al., 1999). A stainless steel tube, closed at one end was inserted into the substrate up to a depth of $60 \mathrm{~cm}$, using a sledge hammer. Between 5 and 10 litres of liquid Nitrogen was then poured down the tube over a 15-20 minute period, freezing the interstitial water. The sediment freezes to the outside of the pipe, and a columnar core of frozen sediment may be removed from the bed using winching apparatus. Nine $60 \mathrm{~cm}$ cores per riffle and 5 were taken from each pool, satisfying Thoms's (1992) freeze-core sampling protocol, with a total dry sample weight of $47 \mathrm{~kg}$ (mean core weight $=15 \mathrm{~kg}$, standard deviation $=7.2 \mathrm{~kg}$ ). Cores were then split into $15 \mathrm{~cm}$ sections, with data for the near surface $15 \mathrm{~cm}$ (that comparable with the basket trap depths) being presented in this study, and more detailed data presented elsewhere (Milan et al., 1999; Milan 2000). The total dry sample weight for the near surface $15 \mathrm{~cm}$ of sediment was $132 \mathrm{~kg}$, 
sufficient to represent grain-sizes up to 170 mm using Church et al.'s (1987) most relaxed 5\% bulk sampling criterion.

\section{Basket trapping}

A novel cell-based sampling strategy was employed to capture spatial variability in processes operating within riffles, specifically to identify differences in fine sediment infiltration between riffle heads, crests and tails, and right, mid and left sides of the channel, and differences between riffles and pools. Three riffles were each split up into nine cells, and the intervening pools treated as a single cell (Figure 1b, c). Basket traps similar to those used by Lisle and Eads (1992) and Sear (1993) were emplaced in the center of each cell, during low flow conditions. Each basket was constructed from a galvanised zinc wire $1 \mathrm{~cm} \mathrm{mesh,} \mathrm{and}$ permitted intragravel flow. At the base of each basket a collapsible bag with a wire collar was inserted (Figure 2). Each basket was filled with a locally-derived matrix-free gravel framework and armour particles were placed on top of the trap. In effect this simulates the initial redd condition immediately after construction by the female fish, which has been reported to reduce the fine sediment content (Kondolf et al., 1993). Traps located on the riffles were operational for the full duration of the study and were emptied on fourteen occasions following flood events of varying magnitudes over a year from ( $18^{\text {th }}$ January 1996 to $11^{\text {th }}$ March 1997). Traps located in the pools were not operational until December 1996. Unfortunately, no samples could be retrieved from the trap situated in the deepest of the pools in the study reach (pool 1). This was initially due to difficulty in accessing the trap during high winter flow conditions, and the subsequent loss of the trap during a flood. Following removal of the armour layer, leads attached to the collar permitted the mixture of infiltrated fines and gravel framework to be removed, leaving the wire basket in the river bed. The fines were separated from the framework material whilst in the field, by washing the fines through $<2 \mathrm{~mm}$ sieve into a bucket. The collapsible bag was replaced at the bottom of each trap, and then the clean framework gravel and armour layer replaced, ready for the next flood event. The baskets did not provide information on vertical patterns of infiltration.

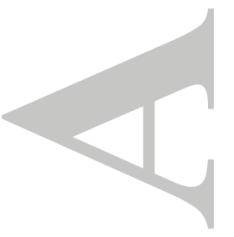




\section{Grain-size analysis}

Sediment samples were oven dried at $40{ }^{\circ} \mathrm{C}$ prior to sieve analysis. Freeze-core samples were dry sieved through $63,37.5,20,6.3$ and $2 \mathrm{~mm}$ aperture sieves, following other freeze-core sampling work undertaken on upland streams in the UK by the author (Milan et al., 2000). For the $<2 \mathrm{~mm}$ material retrieved from freeze-coring and basket sampling, $100 \mathrm{~g}$ sub-samples of the were wet sieved down to $0.063 \mathrm{~mm}$. Sub $0.063 \mathrm{~mm}$ from freeze-cores were analysed using laser diffraction. This paper focuses upon spatial and temporal infiltration rates of the sand fraction based upon the weight of infiltration material per unit area, per epoch (time period between sampling), and the association between infiltration rate and shear stress.

\section{Derivation of trap-specific boundary shear stress}

Boundary shear stress $\tau_{o}$ was derived from the St Venant equation,

$$
\tau_{o}=\rho g R_{h}\left(s-\frac{\partial d}{\partial x}-\frac{u}{g} \frac{\partial u}{\partial x}-\frac{1}{g} \frac{\partial u}{\partial t}\right)
$$

where $\rho$ is the fluid density, $g$ is gravitational acceleration, $R_{h}$ is the hydraulic radius, $s$ is the energy gradient derived from water surface slope, $x$ is longitudinal distance, $t$ is time and $u$ is cross-section average velocity $\left(\frac{Q}{A}\right)$, where $Q$ is discharge and $A$ is the wetted crosssection area. Water depth $(d)$ is commonly substituted for $R_{h}$ and is an appropriate approximation in channels with high width:depth ratios. This data was obtained from a tachometric survey of the bed morphology at cross-sections running across the line of each trap and from rating curves of the water surface relative to each section for flows between 0.1 and $8.6 \mathrm{~m}^{3} \mathrm{~s}^{-1}$ (Milan, 2000). Discharge was recorded at a gauging station located at the study location (see GS, Figure 1b). Subtraction of water surface elevation from the local bed elevation at each trap location gave $d$.

The unsteady term $\left(\frac{1}{g} \frac{\partial u}{\partial t}\right)$ in Eq. (1) can be neglected as steady-state shear stress, rather than time-varying shear stress over the range of the natural hydrograph, is being estimated. 
Milan (2001) have demonstrated the non-uniform flow term $\left(\frac{\partial d}{\partial x}-\frac{u}{g} \frac{\partial u}{\partial x}\right)$ to be negligible over the reach for the full range of flows considered. Their analysis established the ratio between propulsive and resistive forces $(\beta)$ over the flow regime, at length scales equivalent to those of the riffles and pools in the reach (between 6 and $36 \mathrm{~m}$ ). Strongest non-uniform effects were found at a discharge of $2 \mathrm{~m}^{3} \mathrm{~s}^{-1}$. At this flow, strong accelerative effects were shown between pool 2 and riffle 2, and pool 3 and riffle 3 , where $\beta$ deviations from unity of 0.19 and 0.49 were found. Less strong decelerative effects were shown between riffle 2 and pool 3 where there was a deviation of 0.2 from unity. The only other notable deviation is shown at a discharge of $7.26 \mathrm{~m}^{3} \mathrm{~s}^{-1}$ between pool 2 and riffle 2 where flow deceleration results in a $\beta$ value of 0.31. Although Milan et al. (2001) conclude that it appeared reasonable to approximate the flow as being uniform, it is recognized that some uncertainty must still exist in the application of the slope-depth product to produce local $\tau_{o}$ values.

\section{Sediment transport mechanism}

The Rouse number $P$ (Rouse, 1937) for sediments entering the traps over the entire study period was ascertained to identify the predominant mode of transport of sand delivered to the basket traps, derived from

$$
P=\frac{\omega_{s}}{\kappa u_{*}}
$$

where is $\omega_{s}$ settling velocity, $\kappa$ is the von Karman constant, $\kappa=0.4$, and $u_{*}$ is the shear velocity, calculated as

$$
u_{*}=\sqrt{\frac{\tau_{o}}{\rho}}
$$

Trap-specific $\tau_{o}$ for hydrograph peaks in between sampling are used in Eq. (3) above.

Settling velocity was calculated using the drag law based on Dietrich (1982) and Ferguson and Church (2006). Their equation is 


$$
\omega_{s}=\frac{R g D^{2}}{C_{1} v+\left(0.75 C_{2} R g D^{3}\right)^{0.5}}
$$

where $R$ is submerged specific gravity $\left(\frac{\rho_{s}-\rho}{\rho}\right)$, where $\rho_{s}$ is sediment density, $D$ is the median sediment diameter, $v$ is kinematic viscosity of water, and $C_{1}$ and $C_{2}$ are constants related to the shape and smoothness of natural grains $\left(C_{1}=18 ; C_{2} 1.0\right)$. The results of this analysis are shown for each of the riffles in Figure 3, where the mode of transport at flood peaks mainly appears to be split between bedload and the suspended load/bedload transition. It is likely that much of the sediment transported as suspended load and some of the washload enters the traps on the falling limb of the hydrograph when trap-specific $\tau_{o}$ is lower.

\section{Local morphological control}

Relative roughness was used to assess the influence of local bed morphology upon fine sediment infiltration, and was calculated by fitting a 'datum' line that passed through the lowest pool troughs (pool 1 and 4) in the study reach (Figure 4), with a slope equivalent to that of a regression line fitted to the bed long-profile. The elevation difference between the bed and the datum line at the position of each trap $\left(k_{f}\right)$ was then divided by local flow depth (d) estimated for each flow peak in each of the 14-epochs, derived from rating curves (Milan, 2000). Assuming that morphological change was negligible over the period of a single flood event, this provided a measure of the protrusion of the bed morphology into the flow at each trap location, over the flow regime; with greater relative roughness exhibited at lower discharges (Sargent, 1979). In general terms bars and riffles have greater relative roughness in comparison to pools and glides.

\section{RESULTS}

\section{Boundary shear stress}

Boundary shear stress for riffle heads, crests, tails and for pools for a range of discharges from baseflow up to bankfull discharge are shown in the box and whisker plots in Figure 5. Overall there was a gradual increase in overall $\tau_{o}$ with discharge for all morphological units. 
Boundary shear stress data suggests greater sediment transport potential towards riffle tails and in pools; a) there was a clear tendency for a gradual increase in $\tau_{o}$ from the riffle head towards the riffle tail (at flows of $0.1 \mathrm{~m}^{3} \mathrm{~s}^{-1}, 2 \mathrm{~m}^{3} \mathrm{~s}^{-1}$, and $7.26 \mathrm{~m}^{3} \mathrm{~s}^{-1}$ ), although this effect was less evident at the highest discharge, and b) pools show higher $\tau_{o}$ compared with riffle heads at lower discharges $\left(0.1 \mathrm{~m}^{3} \mathrm{~s}^{-1}, 2 \mathrm{~m}^{3} \mathrm{~s}^{-1}\right.$, and $\left.5.44 \mathrm{~m}^{3} \mathrm{~s}^{-1}\right)$.

\section{Baseline sediment character}

Summary statistics for the armour layer median grain-size $\left(D_{50}\right)$ are shown in Table 2 . A notable feature was the coarse nature of the pools $\left(D_{50}=109 \mathrm{~mm}\right)$ in comparison to the riffles $\left(D_{50}=83 \mathrm{~mm}\right)$, thought to be due to the hydraulic characteristics experienced over the flow regime (Milan et al., 2001), and the relative pathways of both coarse (Milan et al., 2002; Milan, 2013) and fine sediment (Milan and Large, 2014). Riffle C was the coarsest riffle, possibly reflecting greater hydraulic energy compared to the other two riffles.

Summary statistics for the sub-surface sediments are shown in Table 3. There was less difference in the sub-surface grain-size characteristics between riffles and pools overall, with riffles slightly finer $\left(D_{50}=45 \mathrm{~mm}\right)$ than the pools $\left(D_{50}=48 \mathrm{~mm}\right)$. Although $<2 \mathrm{~mm}$ concentrations were similar between pools and riffles, with just over $11 \%$, this is likely to be influenced by an outlier (pool 1). There was more variability between the four pools sampled, compared to the riffles; pool 1 was much coarser and held much lower concentrations of fines in comparison to the other three pools.

\section{Temporal patterns of infiltration}

The time series for overall infiltration rates are demonstrated in Figure 6b, alongside the discharge information (Figure 6a) for the same period (15 $5^{\text {th }}$ March 1996 to $11^{\text {th }}$ March 1997). Overall individual basket infiltration rates (for riffles) ranged between 0.0013 and $1.527 \mathrm{kgm}^{--}$ ${ }^{2} \mathrm{day}^{-1}$. The limited data for pools suggested a much lower infiltration rate on average in comparison to riffles, with the exception of Pool 3. The highest rate of infiltration was found in traps at Riffle B after a flow of $7.12 \mathrm{~m}^{3} \mathrm{~s}^{-1}$. The mean temporal rate of infiltration showed a similar pattern between riffles however slight variations were encountered. During the first 
half of the investigation (pre-October 1996) traps at Riffle B appeared to collect greater concentrations of fines coinciding with floods of a lower magnitude $\left(<5 \mathrm{~m}^{3} \mathrm{~s}^{-1}\right)$ than those recorded later on in the study. During the later period it is the traps located at Riffle $\mathrm{C}$ which appear to collect slightly more fines than the other two riffles, a factor particularly evident after discharges greater than $5 \mathrm{~m}^{3} \mathrm{~s}^{-1}$. In the early part of the study when flows recorded were $<5 \mathrm{~m}^{3} \mathrm{~s}^{-1}$ (pre-October 1996) these traps had collected the lowest concentrations of fines. Overall, concentrations of fines collected in the traps during the later part of the study preOctober 1996) are generally greater than those during the earlier part, which appears to be a response to the higher flows experienced during the same period.

\section{Cross-riffle variation}

Cross-riffle data showed a similar temporal pattern for the between-riffle data (Figure 6c), with low rates generally below $0.1 \mathrm{kgm}^{-2} \mathrm{day}^{-1}$, in the early part of the study, and with peaks of up to $0.5 \mathrm{kgm}^{-2} \mathrm{day}^{-1}$, shown later. Although all locations (lb, mid, rb) showed similar patterns in infiltration rates over the study period, significant differences in rates were observed over the study period (one-way ANOVA: $F_{2}, 278=6.71, p<0.01$ ). Traps located towards the left side of the channel consistently recorded the lowest concentrations of fines, indicating that this area was not a major zone for fine bedload routing (Tukey multiple comparisons test: $1 \mathrm{~b}$ versus mid, $p<0.05$, lb versus $r b, p<0.05$ ). Traps located on the right and middle of the channel showed very similar values between October 1996 and January 1997 (Tukey multiple comparisons test: rb versus mid, $\mathrm{p}>0.05$ ).

\section{Down-riffle variation}

The time-series for down-riffle variation is demonstrated in Figure 6d. Lowest infiltration rates once again featured in the early part of the study, whilst highest rates occurred during the series of floods between October 1996 and January 1997, with the peak occurring after a flood of $7.12 \mathrm{~m}^{3} \mathrm{~s}^{-1}$. Although differences between infiltration rates between riffle heads, crests and tails were not found to be statistically significant (one-way ANOVA: $F_{2}, 278=1.47$, $p>0.05$ ), spatial patterns were evident; during the early part of the study (pre-October 1996) the head and crest of the riffles appeared to collect similar amounts of fines. The tail of the riffles consistently had the highest infiltration rates, possibly reflecting increased delivery to this area related to high $\tau_{o}$ at low flow, relative to other parts of the riffle (Figure 5). This 
pattern appeared to be lost after higher magnitude flows between October 1996 and January 1997, only to re-appear once more after two lower flows (February 1997). It was the traps located at the crest of the riffle, that exhibited the highest infiltration rates after larger floods, whereas the head of the riffle had a tendency to record the lowest rates at these flows.

Intermediate and low discharges however appeared to encourage high infiltration at the tail of a riffle.

\section{Pool-riffle variation}

Pools 2 and 4 (see Figure 6b) consistently showed less infiltration of fines in comparison to the riffles up- and downstream. Pool 2 tended to exhibit the lowest infiltration rates, whilst Pool 3 exhibited the highest, and on two occasions this pool collected more fines than the adjacent riffles. Notably, Pool 3 was not as deep as the other two pools, and was situated on a straight section of channel. Fines had to be fed through this pool, whereas on meandering sections, fines could be fed over bar surfaces instead of through the pool trough.

Overall there was a tendency for greatest rates of infiltration to be associated with the higher flow events; particularly during the 1996/97 winter. Conversely, lowest infiltration rates were associated with the summer low flow period. This association is shown more clearly in Figure 7, where infiltration rate is plotted against discharge. When the mean data is considered, a strong dependence between total deposition and discharge was shown $\left(\mathrm{r}^{2}=0.7\right.$, $\mathrm{p}<0.01$ ); a finding also noted by Maturana et al. (2014). Extrapolation of the regression equation suggested that fine bedload movement was initiated at discharges in excess of 0.7 $\mathrm{m}^{3} \mathrm{~s}^{-1}$. Error bars, showing $25^{\text {th }}$ and $75^{\text {th }}$ percentiles, were indicative of significant variability; with the greatest variability evident at the highest discharges. The variability indicated that local controls on fine sediment infiltration were important.

\section{Grain-size character of infiltrating fines}

The grain size distribution for fine sediments infiltrating the traps is shown in the histogram in Figure 8. Ninety percent of the material infiltrating the traps was sand $(>0.063 \mathrm{~mm})$, with dominant modes in the $0.063-0.125 \mathrm{~mm}$, and $0.25-0.5 \mathrm{~mm}$ size range. 
Temporal variations in down-riffle median grain size for sand $(0.063-2 \mathrm{~mm})$ are shown in Figure $9 \mathrm{~b}$. Coarser sediments were found to infiltrate traps in response to the higher magnitude flood events experienced in the later half of the study. Significant differences were found in the grain-sizes of material entering riffle head, crest and tail traps over the study period (one-way ANOVA: $\mathrm{F}_{2}, 225=4.27, \mathrm{p}<0.05$ ). There was a tendency for either the crest (and less frequently the tail) of the riffles to collect coarser sediments (Tukey multiple comparisons test: head versus tail, $\mathrm{p}<0.05$ ), with the head of the riffle consistently collected the finest sediments.

Temporal variations in cross-channel grain-size characteristics for sand infiltrating right-bank (rb), channel center (mid) and left-bank (lb) traps are shown in Figure 9c. There was a trend for retrieval of coarser material in the later part of the study (post-October 1996), which appeared to reflect higher magnitude flows experienced during this period. Overall there was a significant difference in the grain-size of material infiltration traps across the channel (oneway ANOVA: $F_{2}, 243=14.32, p<0.01$; Tukey multiple comparisons test: $1 \mathrm{~b}$ versus mid, $\mathrm{p}<0.01, \mathrm{rb}$ versus mid, $\mathrm{p}<0.01$ ), with significantly coarser material accumulating in traps located in the center of the channel. Left-bank traps tended to collect the finest material up until October 1996, whereas the right-bank traps collected the finest material from late November 1996 through until mid January 1997.

\section{Temporal enrichment}

The ratio of each grain-size class in the bedload $(0.125-2 \mathrm{~mm})$ deposited into the traps, compared with the background levels present in the substrate, retrieved from freeze-cores, is shown as a time-series plot alongside the discharge hydrograph for the study period (Figure 10). The enrichment index $\left(p_{i} / f_{i}\right)$, where $p_{i}$ and $f_{i}$ are the proportions of each size fraction in the sub-surface and infiltrating fines respectively, showed clear temporal and size-dependent patterns. Coarser sands (both the 1-2 mm and 0.5-1 mm categories) had a tendency to be enriched during periods of higher discharge. Conversely, lowest concentrations of these size classes were found during low flow periods, particularly over the summer months. The finer sand-size categories considered (0.25-0.5 and 0.125-0.25 mm), showed the opposite pattern; tending to be enriched during low flow periods and depleted during winter peaks flows. 


\section{Dependence of infiltration upon shear stress}

The overall relationship between infiltration of $<2 \mathrm{~mm}$ material and local $\tau_{o}$ for riffles $\mathrm{A}, \mathrm{B}$, and $\mathrm{C}$, and the pools are shown in Figures 11. Sub-2 mm loadings tended to show a clear association with $\tau_{o}$, although there was considerable scatter caused by a number of factors. Firstly, variable local hydraulic conditions in the vicinity of each trap could result in local variation in sediment transport. Secondly, variation in local sedimentary structure within and between riffles may also be responsible for limiting supply and may alter local hydraulic conditions. Thirdly, the permeable nature of the traps may have allowed some postdepositional intragravel modification of material before it was sampled. The range of $\tau_{o}$ which mobilised fine bedload was wider for the Riffle A and C traps in comparison to those situated on Riffle $\mathrm{B}$, where $\tau_{o}$ ranged between $20-70 \mathrm{Nm}^{-2}$. Infiltration of fine bedload in Riffle A traps appeared to show the strongest dependence upon $\tau_{o}$, whereas the dependence of infiltration rate upon $\tau_{o}$ is not as strong for Riffle B and C (Table IV). The poor relationship shown for Riffle $\mathrm{C}$ data is partly a reflection of small quantities of infiltration of fine bedload below $10 \mathrm{~N} \mathrm{~m}^{-2}$, which is not a feature shown at traps on the other riffles.

Although fewer data were available, a clear dependence of infiltration rate upon shear stress was also exhibited for the pools, over a shear stress range of $20-200 \mathrm{Nm}^{-2}$.

Rating relations for individual riffle traps for $<2 \mathrm{~mm}$ material are shown in Table IV and for riffle A traps only in Figure 12. Less scatter was evident for individual traps, as fewer data are being considered (14 data points; one for each epoch). For the traps situated at the head of Riffle A (Figure 12a) low rates of infiltration were found at $\tau_{o}$ below $50 \mathrm{Nm}^{-2}$, whereas much greater rates were found for $\tau_{o}>50 \mathrm{Nm}^{-2}$. At the riffle head, trap A3 had a tendency to collect higher concentrations of fines for a given $\tau_{o}$. This may have been due to the proximity of the trap to the left-bank, immediately below a point bar; on the Rede bars appeared to act as sources of fines rather than pools, which are clean of fines at base-flow. Data for the crest of Riffle A are shown in Figure 12b, where highest infiltration rates were found at $\tau_{o}>60 \mathrm{Nm}^{-2}$, and rating relations were all very similar (Table IV). The channel center trap A5 tended to show the greatest infiltration particularly at higher $\tau_{o}$. Data for the tail of Riffle A, shown in Figure $12 \mathrm{c}$, demonstrated that most transport was triggered at slightly greater $\tau_{o}$ than those 
experienced further up-riffle, at around $100 \mathrm{Nm}^{-2}$. The highest infiltration rates for a given $\tau_{o}$ tended to be located at trap A8 in the channel center. Conversely trap A9 recorded the lowest rates of infiltration for a given $\tau_{o}$. Trap A9 was situated in an area of high $\tau_{o}$ in the order of

$90 \mathrm{Nm}^{-2}$. It is possible that some of the finest fractions, which had been deposited in the trap, may have been subsequently flushed out by lower magnitude flows before the trap was sampled. For most traps there was a strong relationship between $\tau_{o}$ and infiltration of fines.

However some traps, particularly those located on Riffle C, did not display a strong relationship between these two variables (Table IV). Infiltration in these traps must therefore depend upon other variables such as relative roughness.

\section{Dependence of infiltration upon relative roughness}

Riffle heads, margins and bar tops had higher relative roughness than riffle tails, centres and pools. Areas of low relative roughness are likely to be the preferred zones of sediment routing as these areas are competent for longer periods of time and experience greater tractive force compared to zones of high relative roughness. Therefore it may be expected that riffle heads and margins, with greater relative roughness, would tend to have lower infiltration rates in comparison to riffle centres and tails, with lower relative roughness (Figures $6 \mathrm{c}$ and d). The plot of relative roughness versus infiltration in Figure 13 provides the expected pattern, with a negative exponential relationship between relative roughness and infiltration; with least infiltration in traps situated on the higher relative roughness elements, and highest infiltration on the low relative roughness areas. The higher rates of infiltration in these areas reflect enhanced delivery of material; greater length of time where flows are competent enough to transport material to the trap, and may also reflect enhanced downward hydraulic forces. The bed surface in lower elevation areas always appeared clear of fines at low flow, indicating the efficient flushing of material on the falling limb of the hydrograph. This flush-out of fines however did not appear to influence the quantity of material stored in the traps, although there was a suggestion that it may influence its grain-size.

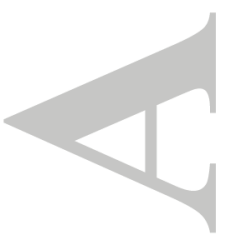




\section{DISCUSSION}

The infiltration rates of fine sediments measured for the River Rede are comparable to some previous investigations (Table I), for example those measured by Sear (1992a) in the adjacent North Tyne catchment. Infiltration rates tended to be higher than some studies on chalk streams (Acornley and Sear, 1999; Welton, 1980), and other lowland streams (Thoms, 1987), where most infiltrated fines are derived from suspended sediments rather than bedload. Conversely, infiltration was not as high as those reported on some other high energy streams (Zimmerman and Lapointe, 2005; Schindler Wildhaber et al., 2012)

\section{Seasonal trends}

The clear association between infiltration rates and discharge, with greatest rates of infiltration being associated with high winter flows is a feature supported by other investigations (Maturana et al., 2014). Higher winter discharges have the competence to transport greater quantities of bedload, however the supply of sand is also a key factor. The main sources of fines on the Rede are from erosion scars/bluffs in slope-channel coupling zones, in-channel supply, and run-off from surrounding moorland. Low and intermediate magnitude $\left(<3 \mathrm{~m}^{3} \mathrm{~s}^{-1}\right)$ events are likely to be responsible for re-working in-channel sources, such as those deposited on bar surfaces, or on the lee of large clasts, and introducing finer grades from run-off into the channel. Larger events are more likely to introduce coarser fines derived from slope-channel coupling zones. During the winter months these areas become much more active as erosion bluffs become saturated with rainwater, and experience the effects of freeze-thaw action. In addition, flood-driven disturbance of the bed structure (armour) results in more frequent release of sand held in gravel voids during this period. The main in-channel source area for fine bedload on the Rede is likely to be point bars, where fines are either stored as interstitial deposits or as fine sediment drapes on the lee side of the bars. Point bars tend not to be armoured, and thus the sediment mixture is easily entrained during floods. This finding is supported by the modelling work of Maturana et al. (2014) and sand tracing work (Milan and Large, 2014) conducted at the Rede site that showed surficial deposits of sand were found on bars and riffle margins, but not pool troughs, contrasting with other studies that have shown pools to act as fine sediment stores during low flow (Lisle and Hilton, 1999). 
Clear seasonal trends appeared to exist in the proportions of different size classes delivered to basket traps. The enrichment effect of coarser material at high flow may be explained through a number of factors including exhaustion of finer grades, enhanced transport and delivery of coarser grades in areas of higher $\tau_{o}$, post-depositional flush-out of finer grades (Schächli, 1992; 1995), and dilution effects. In addition, some of the finer grades may become washload during elevated flows and pass through the reach without infiltrating traps. A seasonal change in sediment source within the catchment may also explain the change in grain-size of sediments accumulating in traps. Similar enrichment and exhaustion effects have also been reported previously for a nival discharge regime (Church et al., 1991).

The finest fractions of the sand bedload $(<0.5 \mathrm{~mm})$, harmful to the early embryonic stages of the salmonid life-cycle, are more prevalent following lower energy discharge events and reduced flood frequency (during the summer), whereas coarser sand (0.5-2 mm), that can prevent alevin escape through blockage of interstitial voids, have a tendency to be delivered in response to higher magnitude and frequency flows during the winter. The timing of embryo incubation, October-February for brown trout in upland streams in the UK (Crisp and LeCren, 1970), relative to the nature of the hydrograph and sediment supply is therefore a critical determinant in the success of embryo incubation.

\section{Spatial patterns of infiltration}

Spatial variations in $\tau_{o}$ over the flow regime result in significant spatial variability in fine sediment infiltration at the scale of a single riffle, implying significant variability in potential survival rates for developing salmonid embryos. Highest infiltration tended to occur in the traps situated on areas of low relative roughness on the riffles (Figure 13), although one pool situated on a straight section of channel registered higher values occasionally (Figure 6). Although median shear stresses appeared to equalize between morphological units at high flow, some of the lower elevation areas exhibited the highest tractive force during periods of high flow, indicated by the whiskers on Figure 5e; hence the high infiltration reflected the high rates of delivery to traps located in these areas.

Maximum rates of infiltration tended to be found in the channel center along the line of the thalweg (Figure 6c), supporting the findings of Frostick et al. (1984) and Thoms (1987). There were significant differences in the amount of fine sediment which infiltrated the 
channel margin traps; the right-bank sometimes showed greatest infiltration and left-bank consistently showed the lowest rate of infiltration. Fines avoided settling in pools situated on channel bends (Pools 2 and 4, Figure 6), however Pool 3, situated on a straight section of channel recorded greater infiltration in comparison to the adjacent riffles, indicating that fines were routed through this pool.

Considering down-riffle variation, lowest rates of infiltration were found at riffle heads, with a gradual increase towards the riffle tail (Figure 6d). Similar findings were found by Mathers and Wood (2016), however in contrast, Thoms (1987) report greatest infiltration at riffle heads. Riffle tails also collected the coarsest material on the Rede, further contrasting with Thoms (1987). Greater infiltration at the riffle tails suggests that these zones are competent for longer durations. Preferential infiltration of coarser sands at riffle tails indicates that this zone is more susceptible to near-surface void blockage, detrimental to the later stages of embryo development. Riffle tail $\tau_{o}$ values are greater than head and crest $\tau_{o}$ for most of the flow range apart from peak flows (Figure 13), resulting in these areas maintaining high transport rates and sediment delivery. Greater $\tau_{o}$ at riffle tails and centers at all but the highest flows (Figure 13) may transport coarser sand for longer durations compared with other areas of the riffle. Post-depositional modification of infiltrated fines may also occur in zones of high $\tau_{o}$, flushing out silt and fine sand from near-surface interstices within traps prior to sampling (Schächli, 1995).

Over a stable bed, pool-riffle morphology drives flow structure, with converging downwelling helical flow at pool entrances (Thompson, 1986; Rodríguez et al. 2013), associated with high velocity cores, and divergent upwelling over riffles. Near-bed downwelling found in areas of low relative roughness such as where the riffle tail merges into the next pool entrance, may promote infiltration of fine bedload into gravel interstices. Work on pool-riffle intragravel flow, however has shown riffle tails to exhibit upwelling hyporheic flow (Tonina and Buffington, 2009), which should potentially discourage fine sediment infiltration. For the Rede, hyporheic upwelling at riffle tails may either prevent the finer grades $(<0.5 \mathrm{~mm})$ from infiltrating gravel voids, or alternatively flush them out postdeposition. However, hyporheic flows are insufficient to prevent coarse sand (0.5-2 $\mathrm{mm})$ from infiltrating gravel voids, and incapable of flushing it. This could further explain the coarser nature of fines found in traps situated in areas of low relative roughness. 


\section{Catchment-scale fine sediment delivery}

In the UK over the last 20 years there has been particular attention drawn to the impacts of agriculturally-derived fine sediment $(<0.063 \mathrm{~mm})$ on salmonid spawning grounds, delivered to the channel as suspended load (Theurer et al., 1998; Collins and Anthony, 2008).

Significant advances have been made in both the sampling and monitoring of this fraction (Phillips et al., 2000), and identifying the sources of the material through fingerprint modelling (Walling et al., 2003; Collins et al., 2010; Stopps et al., 2012). Attention has also focused upon modelling the impacts of this fraction upon salmonid embryo survival (Sear et al., 2014). However it is clear from this and other studies (Lisle and Lewis, 1992) that in many rivers the dominant fine sediment fractions delivered to gravel voids in salmonid redds are sands and granules $(>0.063 \mathrm{~mm})$, delivered via bedload rather than suspended load. These coarser grades are known to be particularly harmful to the emergence phase of the salmonid life-cycle, through the creation of sand seals, and it is important that the processes responsible for delivery and infiltration of this material into spawning redds are better understood and included in future embryo incubation-to-emergence modelling. A key limitation with models such as SIDO-UK, is the assumption that all infiltration is derived from suspended sediment (Sear et al., 2014). This model has the potential to be modified to include equations that predict fine bedload infiltration based upon its' relationship with $\tau_{o}$ and relative roughness, as demonstrated in this paper.

\section{CONCLUSIONS}

Zones of low relative roughness such as the riffle centers and tails act as preferential routing zones for fine sediment and also tend to transport coarser material in comparison to areas of high relative roughness. Low relative roughness zones are competent to transport fines for longer periods, resulting in longer transport and interstitial flushing periods (removing silt and fine sand). Higher $\tau_{o}$ at riffle tails are also capable of mobilising coarser grades of sand, in comparison to riffle heads. Clear associations exist between 1) local $\tau_{o}$ and infiltration rate, and 2) relative roughness and infiltration rate. Where knowledge exists of the relationship between embryo survival and infiltration rate (Lisle and Lewis, 1992), these associations have to potential to be used to predict the spatial variability in embryo incubation-toemergence. The next generation of incubation-to-emergence models should consider sand delivered as bedload to the redd environment, and will need to consider redd and reach 
sediment transport processes, as well as catchment-scale drivers for hydrograph character and sediment supply over the period of embryo incubation. Restoration of pool-riffle habitat should also consider fine sediment dynamics in their design, and hence may also benefit from simulating the hydraulic and morphological controls on the spatial patterns of infiltration.

Such procedures could aid pool-riffle restoration that targets enhancement of salmonid habitat.

\section{ACKNOWLEDGEMENTS}

The field assistance of Andy Large, Watts Stelling and Peter Donnelly, and the comments of John Buffington and an anonymous reviewer on an earlier manuscript are greatly appreciated.

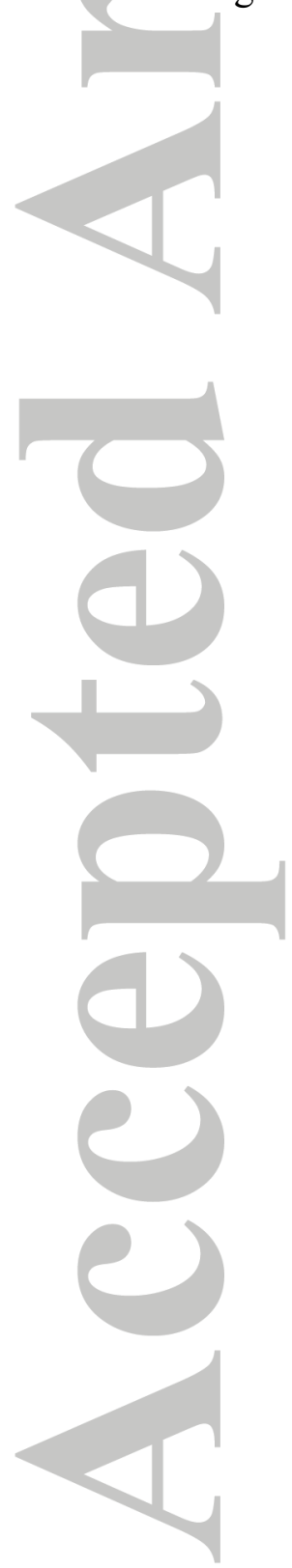




\section{REFERENCES}

Acornley RM, Sear DA. 1999. Sediment transport and siltation of brown trout (Salmo trutta

L.) spawning gravels in chalk streams, Hydrological Processes 13: 447-458.

Allan AF, Frostick LE. 1999. Framework dilation, winnowing, and matrix particle size distribution: the behaviour of some sand-gravel mixtures in a laboratory flume, Journal of Sedimentary Research 69: 20-26.

Beschta RL, Jackson WL. 1979. The intrusion of fine sediment into a stable gravel bed. Journal of the Fisheries Research Board of Canada 36: 204-210.

Briggs JC. 1953. The behavior and reproduction of salmonid fishes in a small coastal stream. Fish. Bull. No. 94. Calif. Dept. Fish and Game. Sacramento.

Brown, L.E., Holden, J. \& Palmer, S.M., 2014. Effects of Moorland Burning on the Ecohydrology of River basins. Key findings from the EMBER project. University of Leeds

Bunte K. 2004. Gravel mitigation and augmentation below hydroelectric dams: A geomorphological perspective. Report to the Stream Systems Technology Center, USDA Forest Service, United States Department of Agriculture, Fort Collins.

Carling PA, MacCahon CP. 1987. Natural siltation of brown trout (Salmo trutta L.) spawning gravels during low-flow conditions. (In Regulated Streams, Craig JF, Kemper TB. (eds). Plenum: 229-224).

Carling PA. 1984. Deposition of fine and coarse sand in an open-work gravel bed, Canadian Journal of Fisheries and Aquatic Sciences 41: 263-270.

Chapman DW. 1988. Critical review of variables used to define effects of fines in redds of large salmonids. Transactions American Fisheries Society 117:1-21.

Church MA, McClean DG, Wolcott JF. 1987. River bed gravels: Sampling and analysis. In Sediment Transport in Gravel-bed Rivers. Thorne CR, Bathurst JC, Hey R. (eds), John Wiley \& Sons Ltd., Chichester, pp. 43-79.

Church MA, Wolcott JF, Fletcher WK. 1991. A test of equal mobility in fluvial sediment transport: behaviour of the sand fraction, Water Resources Research 27: 2941-2951.

Collins AL, Anthony SG. 2008. Assessing the likelihood of catchments across England and Wales meeting 'good ecological status' due to sediment contributions from agricultural sources. Environmental Science and Policy 11: 163-170

Collins AL, Walling DE. 2007. Sources of fine sediment recovered from the channel bed of lowland groundwater-fed catchments in the UK. Geomorphology 88: 120-138.

Collins AL, Zhang Y, Walling DE, Grenfell SE, Smith P. 2010. Tracing sediment loss from eroding farm tracks using geochemical fingerprinting procedure combining local and genetic 
alogorithm optimization. Science of the Total Environment 408: 5461-5471.

Crisp DT, Carling PA. 1989. Observations on siting, dimensions, and structure of salmonid redds. Journal of Fish Biology 34:119-134.

Crisp DT, Le Cren ED. 1970. The temperature of three different small streams in northwest England. Hydrobiologia, 35: 305-323.

Davey GW, Doeg TJ, Blythe JD. 1987. Change in benthic sediment in the Thompson River, Victoria during construction of the Thompson Dam, Regulated Rivers Research and Management 1: 71-84.

Diterich WE. 1982. Settling velocity of natural particles. Water Resources Research 18: $1615-1626$.

Duncan SH, Ward JW. 1985. The influence of watershed geology and forest roads on the composition of salmon spawning gravel. Northwest Science 59: 204-212

Ebise S, Aizaki M, Otsubo K and Muraoka K. 1983. Estimation of River Sediments as Pollutants Loadings. National Institute for Environmental Studies, Japan 6 (2): 93-103.

Einstein HA. 1968. Deposition of suspended particles in a gravel bed, Journal of the Hydraulics Division, ASCE 94: 1197-1205.

European Parliament 2000. Establishing a frame- work for community action in the field of water policy. Directive EC/2000/60, EU, Brussels.

Extence C.A, Chadd RP, England J, Dunbar MJ, Wood PJ, Taylor ED. 2013. The assessment of fine sediment accumulation in rivers using macro-invertebrate community response. River Research and Applications 29:17-55.

Ferguson RI, Church M. 2006. A Simple Universal Equation for Grain Settling Velocity, Journal of Sedimentary Research 74: 933-937

Frostick LE, Lucas PM, Reid I. 1984. The infiltration of fine matrices into coarse-grained alluvial sediments and its implications for stratigraphic interpretation. Journal of the Geological Society of London 141: 955-965.

Greig SM, Sear DA, Carling PA. 2005b. The impact of fine sediment accumulation on the survival of incubating salmon progeny: implications for sediment management. Science of the Total Environment 344: 241-258.

Greig SM, Sear DA, Smallman D, Carling PA. 2005a. Impact of clay particles on cutaneous exchange of oxygen across the chorion of Atlantic salmon eggs. Journal of Fish Biology $6 \mathbf{6}$ : $1681-1691$. 
Hall JD, Lantz RL. 1969. Effects of Logging on the habitat of Coho Salmon and Cutthroat Trout in Coastal streams. In Symposium on Salmon and Trout in Streams, Northcote TJ, (ed) University of British Columbia. HR MacMillan Lectures in Fisheries. 388p.

Hassan MA, Gottesfeld AS, Montgomerry DR, Tuncliffe JF, Clarke GK, Wynn G, Jones-Cox H, Poirer R, MacIsaac E, Herunter H, MacDonald SJ, 2008. Salmon-driven bed load transport and bed morphology in mountain streams. Geophysical Research Letters, 35: L04405.

Heritage GL, Milan DJ. 2004. A conceptual model of the role of excess energy in the formation and maintenance of a riffle-pool sequence. Catena 58: 235-257.

Heywood MJT, Walling DE. 2007. The sedimentation of salmonid spawning gravels in the Hampshire Avon catchment, UK: implications for the dissolved oxygen content of intragravel water and embryo survival. Hydrological Processes 21: 770-788.

Holden J, Shotbolt L, Bonn A, Burt TP, Chapman PJ, Dougill AJ, Fraser EDG, Hubacek K, Irvine B, Kirkby MJ, Reed MS. 2007. Environmental change in moorland landscapes. EarthScience Reviews, 82: 75-100.

Hoopes DT. 1972. Selection of spawning sites by sockeye salmon in small streams. Fishery Bulletin 70(2): 447-458.

Hunter, J.W. 1973. A discussion of game fish in the State of Washington as related to water requirements. Wash. Dept. of Game. Olympia.

Jones JI, Murphy JF, Collins AL, Sear DA, Naden PS, Armitage PD. 2011. The impact of fine sediment on macroinvertebrates. River Research and Applications 28: 1055-1071. Julien HP, Bergeron NE. 2006. Effect of fine sediment infiltration during the incubation period on Atlantic salmon (Salmo salar) embryo survival. Hydrobiologia 563: 61-71.

Kemp P, Sear DA, Collins A, Naden P, Jones I. 2011. The impacts of fine sediment on riverine fish. Hydrological Processes 25: 1800-1821.

Kondolf GM, Sale MJ, Wolman G. 1993. Modification of gravel size by spawning salmonids. Water Resources Research 29: 2265-2274.

Kondolf GM, Wilcock PR. 1996. The flushing flow problem: defining and evaluating objectives. Water Resources Research 32: 2589-2599

Kondolf GM, Williams JG, Horner TC, Milan DJ. 2008. Quantifying physical degradation of spawning habitat. In Salmon spawning habitat in rivers: Physical controls, biological responses and approaches to remediation, Sear DA, DeVries P, Greig S. (eds). American Fisheries Society Symposium, 65, pp249-274. 
Lisle TE, Eads RE. 1991. Methods to measure sedimentation of spawning gravels. USDA Forest Service Research Note PSW-411.

Lisle TE, Hilton S. 1999. Fine bed material in pools of natural gravel bed channels, Water Resources Research 35: 1291-1304.

Lisle TE, Lewis J. 1992. Effects of sediment transport on survival of salmonid embryos in a natural stream: a simulation approach. Can. J. Fish. Aquat. Sci. 49: 2337-2344.

Lisle TE. 1989. Sediment transport and resulting deposition in spawning gravels, North Coastal California. Water Resources Research 25 (6): 1303-1319.

Mathers KL, Millet J, Robertson AL, Stubbington R, Wood PJ. 2014. Faunal response to benthic and hyporheic sedimentation varies with direction of vertical hydrological exchange.

Freshwater Biology 59: 2278-2289.

Mathers KL, Wood PJ. 2016. Fine sediment deposition and interstitial flow effects on macroinvertebrate community composition within riffle heads and tails. Hydrobiologia 776: 147-160.

Maturana O, Tonina D, McKean JA, Buffington JM, Luce CH, Caamano D. 2014. Modeling the effects of pulsed versus chronic inputs on salmonid spawning habitat in a low-gradient gravel-bed river. Earth Surface Processes and Landforms 39: 877-889.

McNeil WL, Ahnell WH. 1960. Measurement of gravel composition of salmon stream beds. University of Washington Fisheries Research Institute Circular, No. 120.

Meehan WR, Swanston DN. 1977. Effects of gravel morphology on fine sediment accumulation and survival of incubating salmon eggs. Research Paper US Forest Service INT-156, 14pp.

Milan DJ, Heritage GL, Large ARG, Brunsdon CF. 1999 Influence of particle shape and sorting upon sample size estimates for a coarse-grained upland stream. Sedimentary Geology 128: $85-100$.

Milan DJ, Heritage GL, Large ARG, Charlton ME. 2001. Stage-dependent variability in shear tractive force distribution through a riffle-pool sequence. Catena 44: 85-109.

Milan DJ, Heritage GL, Large ARG. 2002. Tracer pebble entrainment and deposition loci: influence of flow character and implications for riffle-pool maintenance. Geological Society, London, Special Publications, 191(1), pp.133-148.

Milan DJ, Large ARG. 2014. Magnetic tracing of sand over pool-riffle morphology. Catena 115: $134-149$

Milan DJ, Petts GE, Sambrook H. 2000. Regional variations in sediment structure of trout streams in southern England. Aquatic Conservation 10: 407-420. 
Milan DJ. 1996. The application of freeze-coring for siltation assessment in a recently regulated stream. In; Merot, P. \& Jigorel, A. (eds) Hydrologie dans les pays celtiques. Actes du ler Colloque interceltique d'Hydrologie et de Gestion des Eaux. Organise par CEMAGREF, DIREN, IFREMER, INRA, INSA. Rennes France, 8-11 Juillet 1996, Les Colloques no 79, 253-266.

Milan DJ. 2000. Sand and gravel transport through a riffle-pool sequence. Unpublished PhD thesis, Department of Geography, University of Newcastle upon Tyne, 341pp.

Milan DJ. 2013. Sediment routing hypothesis for pool-riffle maintenance. Earth Surface Processes and Landforms 38: 1623-1641.

Milan, D. J. and Petts, G. E. 1998. Addressing the effects of siltation in a trout stream experiencing excessive low flows: River Glen, UK. In Advances in River Bottom Ecology, Bretschko G, Helesic, J. (eds). Backhuys, Netherlands, pp 279-291.

Milan, D.J. 1994. Sediment quality characteristics of salmonid spawning grounds. Unpublished MPhil thesis, Department of Geography, Loughborough University of Technology, 204 pp.

Pasternack GB, Brown RA. 2013. Ecohydraulic design of riffle-pool relief and morphological unit geometry in support of regulated gravel-bed river rehabilitation. In Ecohydraulics: An Integrated Approach, Maddock I, Harby A, Kemp P, Wood P. (eds), John Wiley \& Sons Ltd.

Petticrew EL, Arocena JM. 2003. Organic matter composition of gravel-stored sediments from salmon bearing streams. Hydrobiologia 494:17-24.

Petts GE, Thoms MC, Brittan K, Atkin B. 1989. A freeze-coring technique applied to pollution by fine-grained sediments in gravel-bed rivers. The Science of the Total Environment: 84, 259-272.

Petts GE. 1984. Sedimentations in regulated rivers. Earth Surface Processes and Landforms 9: $129-134$.

Petts GE. 1988. Accumulation of fine sediment within substrate gravels along two regulated rivers, UK. Regulated Rivers: Research and Management 2: 141-153.

Phillips JM, Russell MA, Walling DE. 2000. Time-integrated sampling of fluvial suspended sediment: a simple methodology for small catchments. Hydrological Processes 14: 2589_ 602.

Reiser DW, Ramay MP, Lambert TR. 1985. Review of flushing flow requirements in regulated streams. Pacific gas and electric company, Department of Engineering Research San Ramon, California, 94583, 97pp.

This article is protected by copyright. All rights reserved. 
Rodríguez JF, García CM, García MH. 2013. Three - dimensional flow in centered pool riffle sequences. Water Resources Research, 49: 202-215.

Rouse H. 1937. Nomogram for the settling velocity of spheres. In Division of Geology and Geography, Exhibit D of the Report of the Commission on Sedimentation, 1936-37, National Research Council, Washington, D.C., pp. 57-64.

Sargent RJ. 1979. Variation in Manning's $n$ roughness coefficient with flow in open river channels, Journal of the Institution of Water Engineers and Scientists 33: 290-294.

Schälchli U. 1992. The clogging of coarse gravel river beds by fine sediment, Hydrobiologia, 235/236: 189-187.

Schälchli U. 1995. Basic equations for siltation of riverbeds. Journal of Hydraulic Engineering 121(3): 274-287.

Schindler Wilhaber Y, Michel C, Burkhardt-Holm P, Banninger D, Alewell C. 2012.

Measurement of spatial and temporal fine sediment dynamics in a small river. Hydrol. Earth Syst. Sci. 16: 1501-1515.

Schwartz JS, Neff KJ, Dworak, FE, Woockman RR. 2015. Restoring riffle-pool structure in an incised, straightened urban stream channel using an ecohydraulic modeling approach. Ecological Engineering, 78: 112-126.

Sear DA, Pattison I, Collins AL, Newson MD, Jones JI, Naden PS, Carling PA. 2014. Factors controlling the temporal variability in dissolved oxygen regime of salmon spawning gravels. Hydrological Processes 28: 86-103.

Sear DA. 1992a. Sediment transport processes in riffle-pool sequences and the effects of river regulation for hydroelectric power in the River North Tyne, Unpublished PhD thesis, University of Newcastle upon Tyne.

Sear DA. 1992b. Sediment transport processes in riffle-pool sequences in a river experiencing hydropower regulation. In Hey RD, Billi P, Thorne CR, Tacconi P. (Eds.), Dynamics of Gravel-bed Rivers, John Wiley, Chichester, pp629-650.

Sear DA. 1993. Fine sediment infiltration into gravel spawning beds within a regulated river experiencing floods: ecological implications for salmonids, Regulated Rivers Research and Management 8: 373-390.

Seydell I, Ibisch R, Zanke U. 2009. Intrusion of suspended sediments into gravel riverbeds: influence of bed topography studied by means of field and laboratory experiments, Advanc. Limnol 61: 67-85, 2009. 
Slaney PA, Halsey TG, Tautz AF. 1977. Effects of forest harvesting practices on spawning habitat of stream salmonids in the Centenial Creek watershed, British Columbia, Fish Management Report 73: 45pp. Province of British Columbia, Mineral, Recreation and Conservation.

Soulsby C, Youngson AF, Moir HJ, Malcolm IA. 2001. Fine sediment influence on salmonid spawning habitat in a lowland agricultural stream: a preliminary assessment. The Science of the Total Environment 265: 295-307.

Stopps J, McEwen LJ, Milan DJ. 2012. Fine sediment sources, sedimentation risk and siltation of salmonid spawning gravels in the Herefordshire Lugg, UK. In: Hydrology for a changing world, Proceedings of the BHS eleventh National Symposium, Dundee, 2012, 1-6.

Tallis JH. 1987. Fire and flood at Holme Moss: erosion processes in an upland blanket mire. Journal of Ecology 75: 1099-129.

Tappel PD, Bjornn TC. 1983. A new way of relating size of spawning gravel to salmonid embryo survival. North Am J Fish Manage. 3:123- 35.

Theurer F D, Harrod TR, Theurer M. 1998. Sedimentation and salmonoids in England and Wales. EA R\&D Technical report P194. Swindon, Environment Agency R\&D Dissemination Centre c/o Water Research Council. pp. 63.

Thompson A. 1986. Secondary flows and the pool-riffle unit: A case study of the processes of meander development. Earth Surface Processes \& Landforms, 11: 631-641.

Thoms MC. 1987. Channel sedimentation in urban gravel-bed rivers. PhD thesis, University of Technology, Loughborough.

Thoms MC. 1992. A comparison of grab- and freeze-sampling techniques in the collection of gravel-bed river sediments. Sedimentary Geology 78: 191-200.

Tonina D, Buffington JM. 2009. A three-dimensional model for analyzing the effects of salmon redds on hyporheic exchange and egg pocket habitat. Canadian Journal of Fisheries and Aquatic Sciences, 66(12): 2157-2173.

Walling DE, Amos CM. 1994. Rivers Piddle action plan, Unpublished report to Southern Region NRA, University of Exeter, 88p.

Walling DE, Collins AL, McMellin GK. 2003. A reconnaissance survey of the source of interstitial fine sediment recovered from salmonid spawning gravels in England and Wales. Hydrobiologia 497: 91-108.

Walling DE, Webb BW. 1987. Suspended load in gravel bed rivers: UK experience. In Sediment transport in Gravel-bed rivers. Thorne CR, Bathurst JC, Hey RD. (eds), Wiley, Chichester, 691-732. 
Walling DE. Collins AL. 2016. Fine sediment transport and management. In River Science: Research and Management for the $21^{\text {st }}$ Century. Gilvear DJ, Greenwood MG, Thoms MC, Wood PJ. (eds.), John Wiley \& Sons, Ltd.

Welton JS, 1980. Dynamics of sediment and organic detritus in a small chalk stream, Archive für Hydrobiologia 90: 162-181.

Wolman MG. 1954. A method of sampling coarse river gravels, Transactions of the American Geophysical Union 35: 951-956.

Wood PJ, Armitage PD. 1997. Biological effects of fine sediment in the lotic environment.

Environmental Management 21(2): 203-217.

Zimmerman AE, Lapointe M. 2005. Sediment infiltration traps: their use to monitor salmonid spawning habitat in headwater tributaries of the Cascapedia River, Quebec. Hydrological Processes 19: 4161-4177.
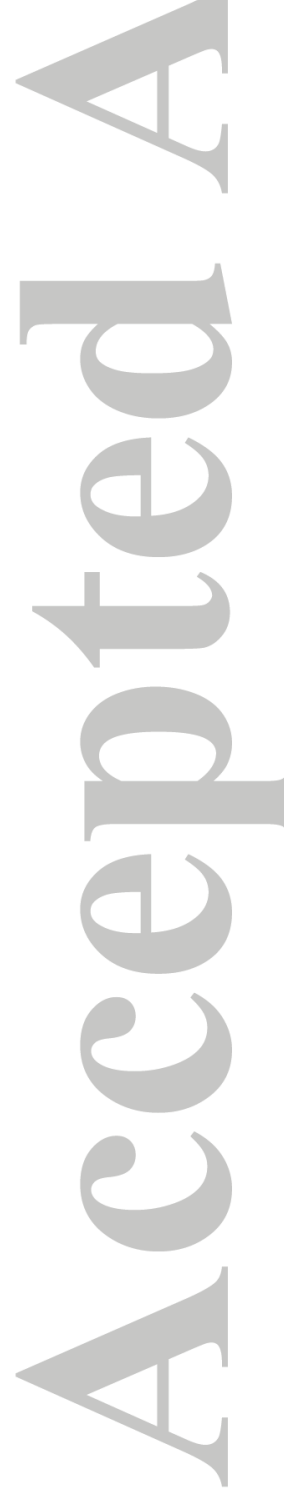
Table I Documented field studies describing accumulation rates of fines in gravel-bed rivers.

\begin{tabular}{|c|c|c|c|c|}
\hline River & Reference & $\begin{array}{l}D_{50} \text { (Framework) } \\
(\mathrm{mm})\end{array}$ & $\begin{array}{l}\text { Rate of } \\
\text { accumulation } \mathrm{Kg} \mathrm{m}^{-} \\
{ }^{2} \text { day }^{-1} \text { ) }\end{array}$ & $\begin{array}{l}\text { Discharge } \\
\text { conditions }\end{array}$ \\
\hline Rede UK & This study & 53 & $0.0013-1.527$ & Variable \\
\hline $\begin{array}{l}\text { Enziwiger, } \\
\text { Switzerland }\end{array}$ & $\begin{array}{l}\text { Schindler Wildhaber } \\
\text { et al. (2012) }\end{array}$ & - & $0.1-10.36$ & Variable \\
\hline - & Seydell et al. (2009) & - & $0.16 \pm 0.07$ & Variable \\
\hline $\begin{array}{l}\text { Cascapedia River, } \\
\text { Canada }\end{array}$ & $\begin{array}{l}\text { Zimmerman \& } \\
\text { Lapointe (2005) }\end{array}$ & - & $0.006-6.8$ & Variable \\
\hline Wallop Brook, UK & $\begin{array}{l}\text { Acornley \& Sear } \\
\text { (1999) }\end{array}$ & 36.5 & $0.0428-0.4071$ & Variable \\
\hline River Test, UK & $\begin{array}{l}\text { Acornley \& Sear } \\
\text { (1999) }\end{array}$ & 21.6 & $0.0143-1.0$ & Variable \\
\hline River Piddle, UK & $\begin{array}{l}\text { Walling and Amos } \\
\text { (1994) }\end{array}$ & 22.6 & $0.0143-0.6429$ & Variable \\
\hline North Tyne UK & Sear (1992a) & 54 & $\begin{array}{l}0.005-0.086 \\
0.004-0.064 \\
0.013-1.574\end{array}$ & $\begin{array}{l}\text { Compensation } \\
\text { Hydropower } \\
\text { Flood }\end{array}$ \\
\hline $\begin{array}{l}\text { Caspar, Jacoby, \& } \\
\text { Prairie Creeks, US }\end{array}$ & Lisle (1989) & $21-25$ & $9-133$ & Flood \\
\hline Black Brook UK & Thoms (1987) & 13 & $\begin{array}{c}0.614 \\
0.26-2.49\end{array}$ & Variable \\
\hline River Blythe UK & Thoms (1987) & 15 & $\begin{array}{c}0.644 \\
0.312-0.861\end{array}$ & Variable \\
\hline River Tame UK & Thoms (1987) & 22 & $\begin{array}{c}0.399 \\
0.008-0.779\end{array}$ & Variable \\
\hline Turkey Brook UK & Frostick et al. (1984) & 27 & $\begin{array}{l}0.24 \\
4.43\end{array}$ & $\begin{array}{l}\text { Baseflow } \\
\text { Flood }\end{array}$ \\
\hline Tadnoll Brook UK & Welton (1980) & 22 & $\begin{array}{c}0.37-0.93 \\
5.00-10.00\end{array}$ & $\begin{array}{l}\text { Baseflow } \\
\text { Flood }\end{array}$ \\
\hline $\begin{array}{l}\text { Great Eggleshope } \\
\text { Beck UK }\end{array}$ & $\begin{array}{l}\text { Carling and McCahon } \\
\text { (1987) }\end{array}$ & 20 & $\begin{array}{c}0.008 \\
0.29-2.5\end{array}$ & $\begin{array}{l}\text { Baseflow } \\
\text { Flood }\end{array}$ \\
\hline Harris Creek Canada & Church et al. (1991) & 20 & $\begin{array}{l}0.03 \\
25.9\end{array}$ & $\begin{array}{l}\text { Baseflow } \\
\text { Nival Flood }\end{array}$ \\
\hline River Sanno Japan & Ebise et al. (1983) & - & $\begin{array}{c}0.401 \\
0.03-1.469\end{array}$ & Variable \\
\hline $\begin{array}{l}\text { Thompson River } \\
\text { Australia }\end{array}$ & Davey et al. (1987) & $<45$ & $\begin{array}{l}0.056-0.307 \\
0.073-0.506\end{array}$ & $\begin{array}{l}\text { Upstream dam } \\
\text { Downstream dam }\end{array}$ \\
\hline $\begin{array}{l}\text { Strawberry Creek } \\
\text { California }\end{array}$ & Reiser et al. (1985) & - & $\begin{array}{c}1.20 \\
0.876-4.56\end{array}$ & Variable \\
\hline East Creek Alaska & $\begin{array}{l}\text { Meehan and } \\
\text { Swanston (1977) }\end{array}$ & - & $\begin{array}{c}0.497 \\
0.320-0.670\end{array}$ & Variable \\
\hline Centennial Creek & Slaney et al. (1977) & 45 & 25.0 & Flood \\
\hline
\end{tabular}


Table II Summary surface layer characteristics of individual geomorphic units

\begin{tabular}{|cccc}
\hline Site & $\boldsymbol{D}_{\mathbf{1 6}}$ & $\boldsymbol{D}_{\mathbf{5 0}}$ & $\boldsymbol{D}_{\mathbf{8 4}}$ \\
\hline Riffles & & & \\
A & 41 & 75 & 133 \\
B & 44 & 84 & 150 \\
C & 56 & 96 & 150 \\
Mean & $\mathbf{4 7}$ & $\mathbf{8 5}$ & $\mathbf{1 4 4}$ \\
& & & \\
& & & 190 \\
Pools & 82 & 120 & 195 \\
1 & 72 & 120 & 170 \\
2 & 86 & 115 & 120 \\
3 & 43 & 82 & $\mathbf{1 6 9}$ \\
\hline
\end{tabular}


Table III Summary substrate grain-size characteristics

\begin{tabular}{|lllll}
\hline Site & $\boldsymbol{D}_{16}$ & $\boldsymbol{D}_{50}$ & $\boldsymbol{D}_{84}$ & $\begin{array}{l}\text { Matrix } \\
(\mathbf{\%})\end{array}$ \\
\hline Riffles & & & & \\
$\mathbf{A}$ & 5 & 44 & 127 & 12.18 \\
$\mathbf{B}$ & 7 & 53 & 136 & 10.13 \\
$\mathbf{C}$ & 3 & 35 & 115 & 12.58 \\
Mean & $\mathbf{5}$ & $\mathbf{4 5}$ & $\mathbf{1 2 9}$ & $\mathbf{1 1 . 5 5}$ \\
Pools & & & & \\
$\mathbf{1}$ & 18 & 52 & 130 & 2.53 \\
$\mathbf{2}$ & 0.5 & 8 & 22 & 22.35 \\
$\mathbf{3}$ & 0.25 & 14 & 49 & 25.24 \\
$\mathbf{4}$ & 7 & 62 & 142 & 10.92 \\
Mean & $\mathbf{7}$ & $\mathbf{4 8}$ & $\mathbf{1 3 3}$ & $\mathbf{1 1 . 3 6}$ \\
\hline
\end{tabular}
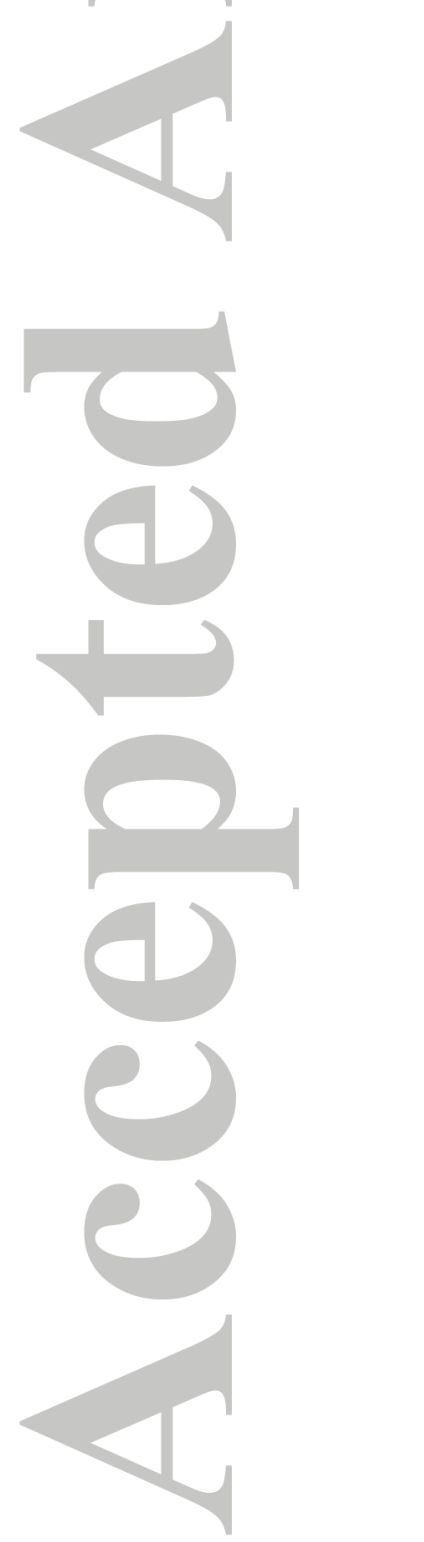
Table IV Log-log regressions for infiltration rate $(I)$ versus shear stress $\left(\tau_{\mathrm{o}}\right)$ for $<2$ mm material. ${ }^{*} \mathrm{p}<0.01, \uparrow \mathrm{p}<0.05$. NS: Not Significant

\begin{tabular}{llll}
\hline Trap number & Riffle A & Riffle B & Riffle C \\
\hline $\mathbf{1}$ & $I=2 \mathrm{E}-04 \tau^{1.47}$ & $I=5 \mathrm{E}-09 \tau^{4.84}$ & $I=3 \mathrm{E}-06 \tau^{3.20}$ \\
& $r^{2}=0.803^{*}$ & $r^{2}=0.949^{*}$ & $r^{2}=0.658 \dagger$ \\
$\mathbf{2}$ & $I=0.001 \tau^{1.21}$ & $I=1 \mathrm{E}-09 \tau^{4.87}$ & $I=0.001 \tau^{1.70}$ \\
$\mathbf{3}$ & $r^{2}=0.449 \dagger$ & $r^{2}=0.837^{*}$ & $r^{2}=0.604 \dagger$ \\
& $I=1 \mathrm{E}-04 \tau^{1.83}$ & $I=7 \mathrm{E}-12 \tau^{5.99}$ & $I=6 \mathrm{E}-05 \tau^{2.09}$ \\
$\mathbf{4}$ & $r^{2}=0.705^{*}$ & $r^{2}=0.628 \dagger$ & $r^{2}=0.08 \mathrm{NS}$ \\
& $I=3 \mathrm{E}-04 \tau^{1.49}$ & $I=4 \mathrm{E}-15 \tau^{7.86}$ & $I=0.001 \tau^{1.07}$ \\
$\mathbf{5}$ & $r^{2}=0.841^{*}$ & $r^{2}=0.722 \dagger$ & $r^{2}=0.474 \mathrm{NS}$ \\
& $I=1 \mathrm{E}-04 \tau^{1.69}$ & $I=8 \mathrm{E}-09 \tau^{4.51}$ & $I=0.001 \tau^{1.76}$ \\
$\mathbf{6}$ & $r^{2}=0.546^{*}$ & $r^{2}=0.810^{*}$ & $r^{2}=0.580 \dagger$ \\
& $I=2 \mathrm{E}-04 \tau^{1.51}$ & $I=5 \mathrm{E}-07 \tau^{3.62}$ & $I=0.003 \tau^{1.26}$ \\
$\mathbf{7}$ & $r^{2}=0.668^{*}$ & $r^{2}=0.469 \dagger$ & $r^{2}=0.374 \mathrm{NS}$ \\
& $I=2 \mathrm{E}-05 \tau^{1.85}$ & $I=3 \mathrm{E}-08 \tau^{3.89}$ & $I=0.002 \tau^{1.16}$ \\
$\mathbf{8}$ & $r^{2}=0.790^{*}$ & $r^{2}=0.953^{*}$ & $r^{2}=0.522 \dagger$ \\
& $I=1 \mathrm{E}-06 \tau^{2.61}$ & $I=1 \mathrm{E}-05 \tau^{2.81}$ & $I=3 \mathrm{E}-05 \tau^{2.53}$ \\
$\mathbf{9}$ & $r^{2}=0.528^{*}$ & $r^{2}=0.892 \dagger$ & $r^{2}=0.397 \mathrm{NS}$ \\
& $I=8 \mathrm{E}-08 \tau^{2.91}$ & $I=3 \mathrm{E}-08 \tau^{4.14}$ & $I=9 \mathrm{E}-05 \tau^{1.66}$ \\
& $r^{2}=0.719 \dagger$ & $r^{2}=0.611 \dagger$ & $r^{2}=0.044 \mathrm{NS}$ \\
\hline
\end{tabular}




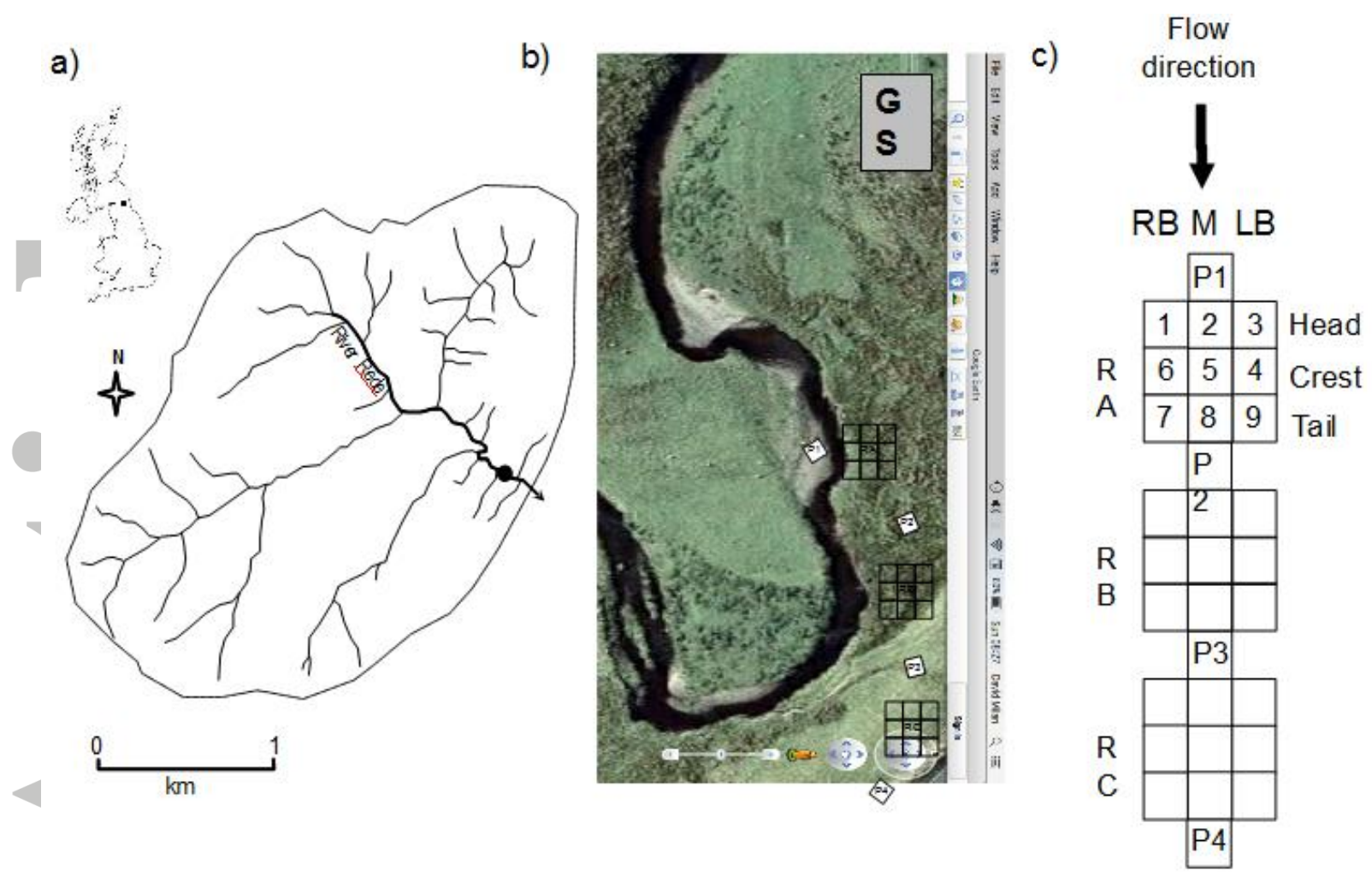

Figure 1 Study Location, a) River Rede catchment, b) aerial photograph of study reach, showing location of sampling cells (Google Earth, 2016), and the location of the gauging station (GS), c) representation of cell-based strategy used to sample pools (P) and riffles (R), right-bank (rb), channel mid line (b), and left-bank (lb), and riffle head, crests and tails. 


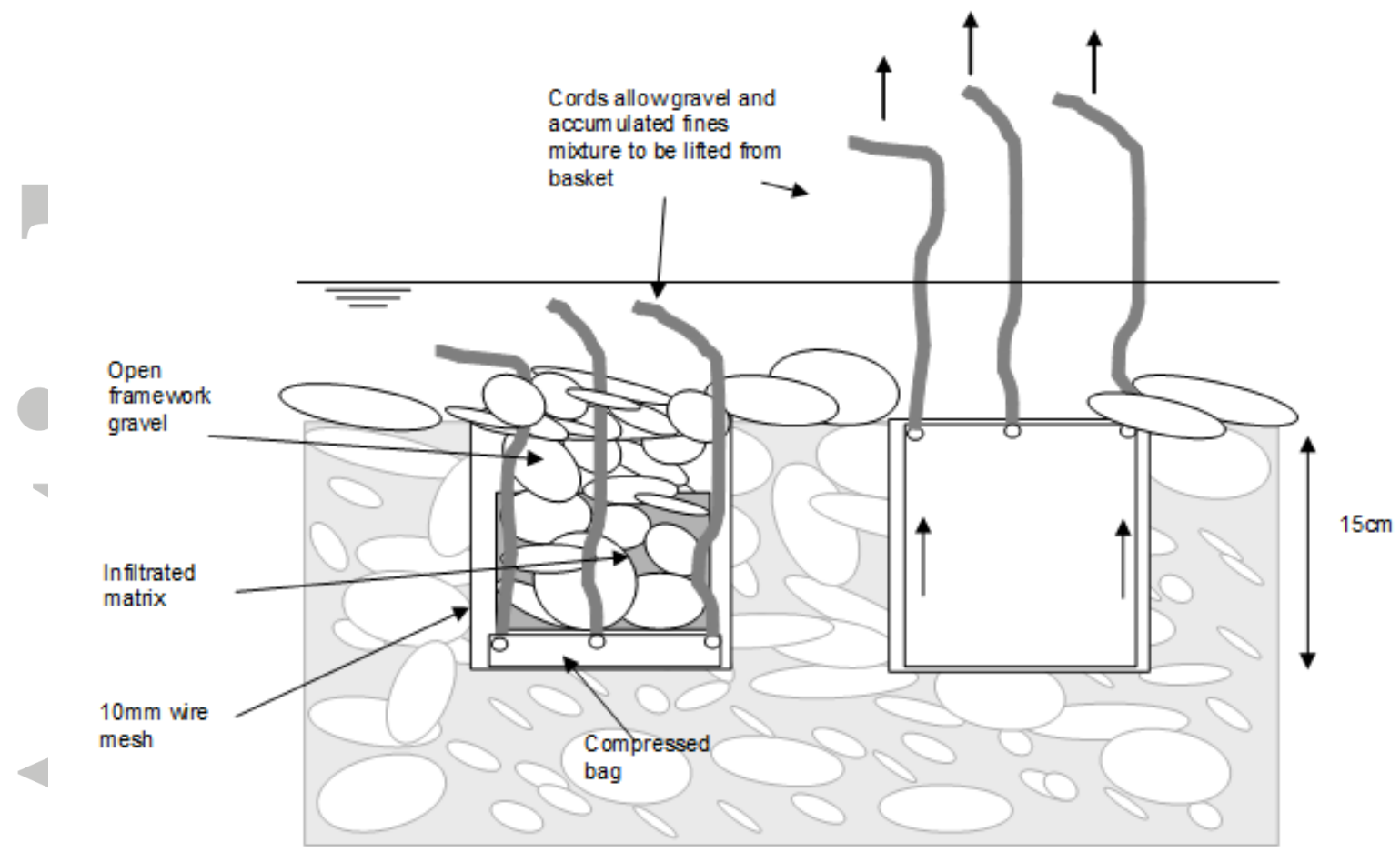

Figure 2 Basket traps used to sample fine bedload sediments. 


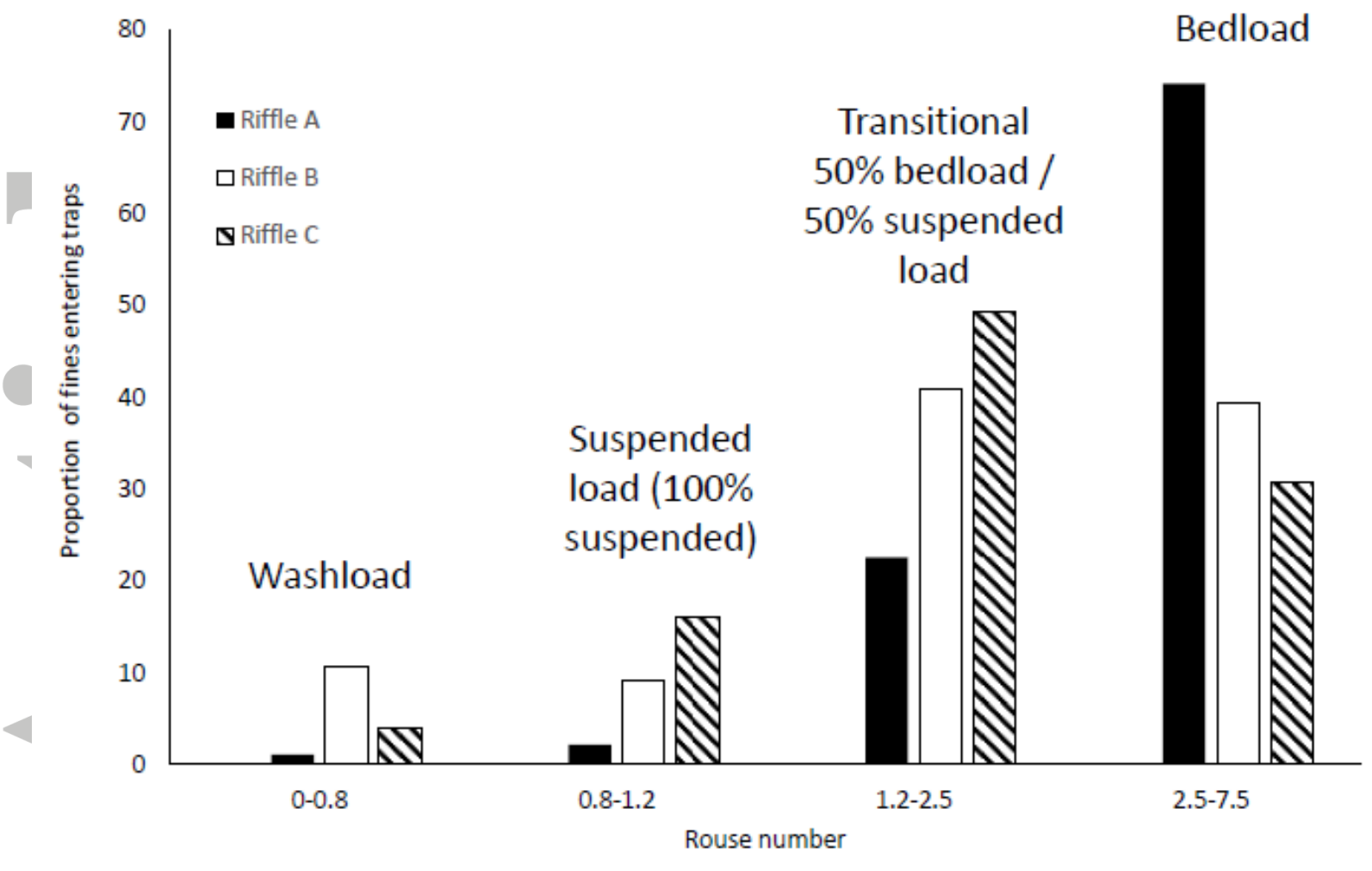

Figure 3 Average Rouse number calculated for basket traps over the study period.

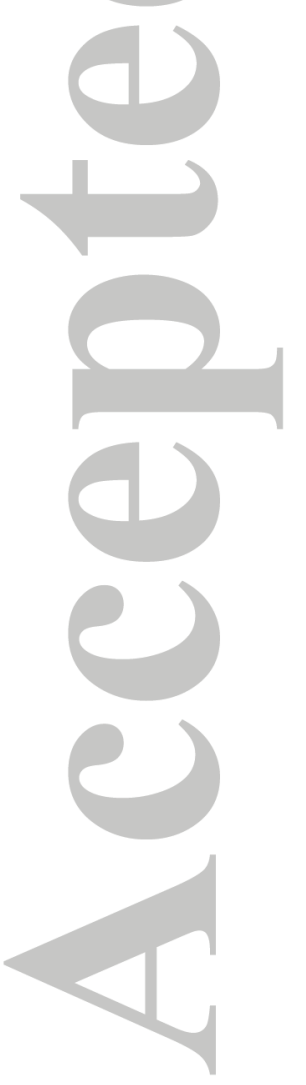




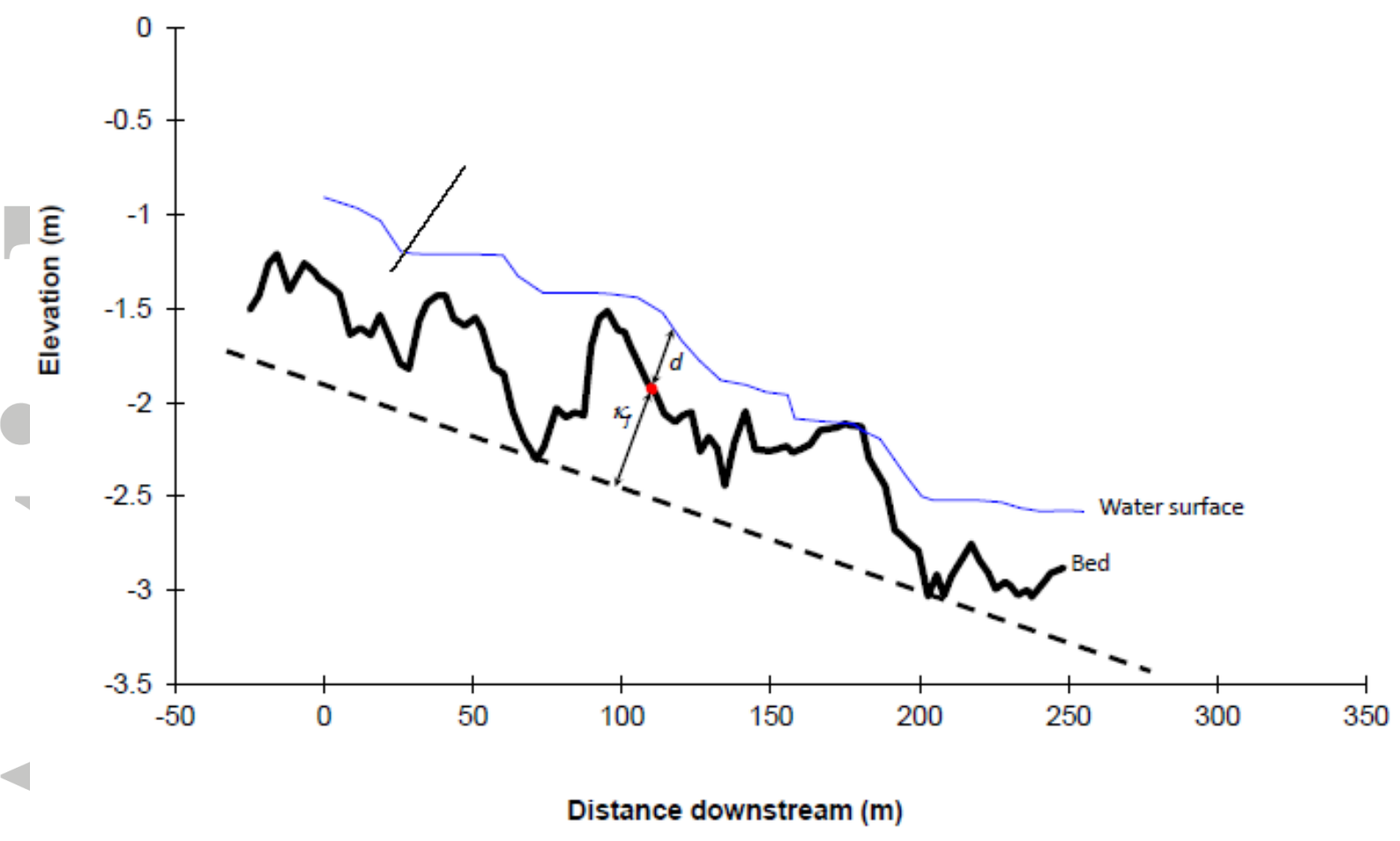

Figure 4 Derivation of relative roughness. Long profile and low flow water surface are indicated. Roughness height $\left(k_{f}\right)$ is the elevation above the regression line fitted to the long profile of the bed, and passing through the lowest pool troughs (pool 1 and pool 4), as indicated by the stippled line. Relative roughness is derived through the ratio of $k_{f}$ to flow depth $(d)$. 


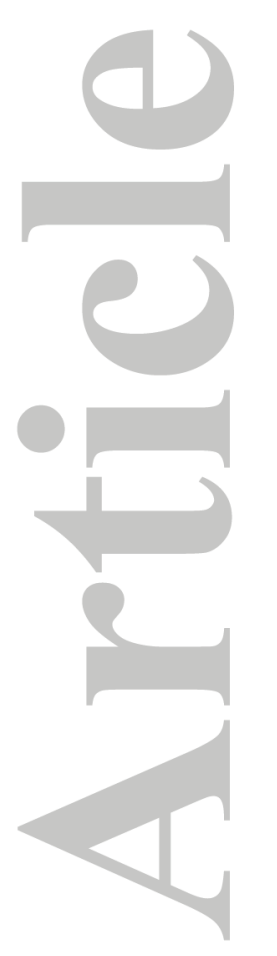

a)

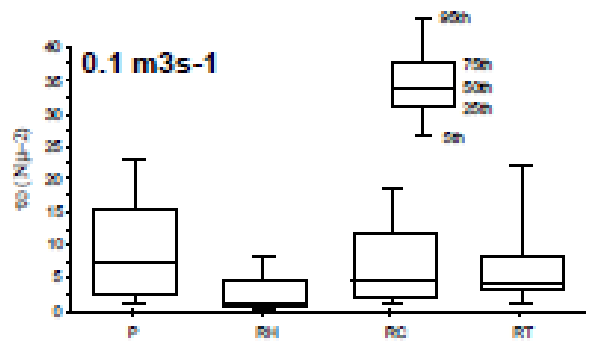

b)

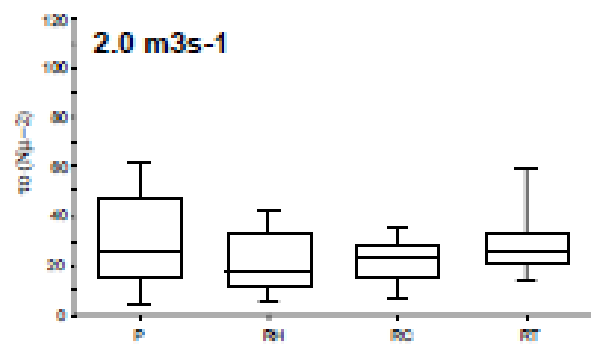

c)

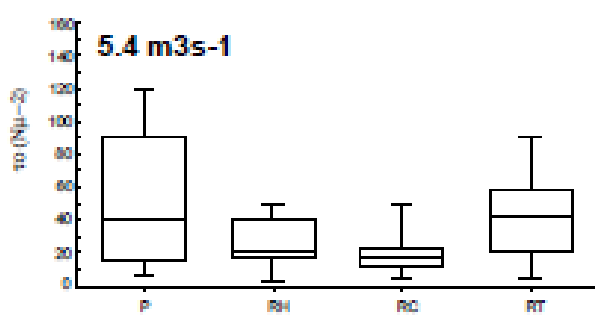

d)
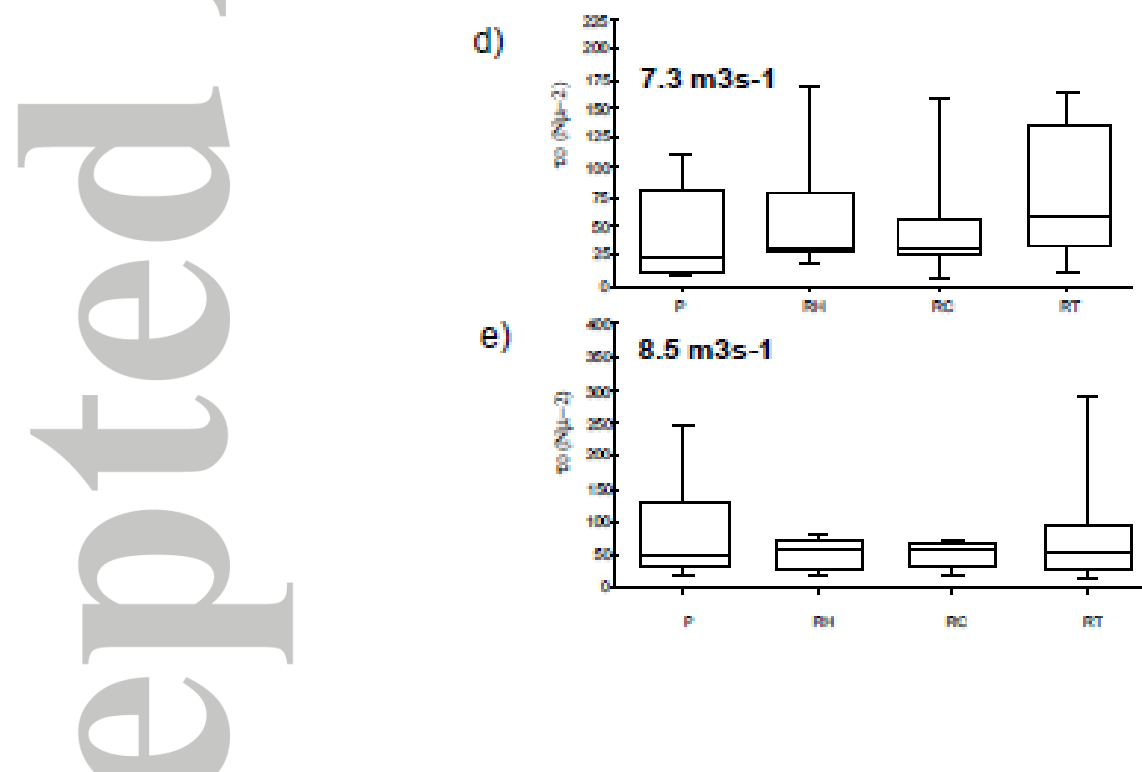

e)

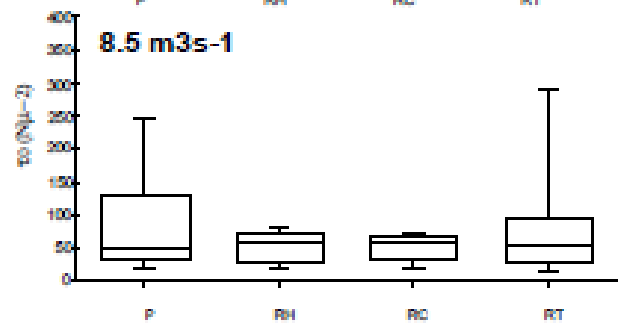

Figure 5 Shear stress variations for different morphology units (P-pools; RH - riffle heads; RC-riffle crests; RT-riffle tails), for different discharges, a) $0.1 \mathrm{~m}^{3} \mathrm{~s}^{-1}$, b) $2 \mathrm{~m}^{3} \mathrm{~s}^{-1}$, c) $5.44 \mathrm{~m}^{3} \mathrm{~s}^{-1}$ d) $7.26 \mathrm{~m}^{3} \mathrm{~s}^{-1}$, e) $8.52 \mathrm{~m}^{3} \mathrm{~s}^{-1}$. Note that the y-axis scale is not uniform. 

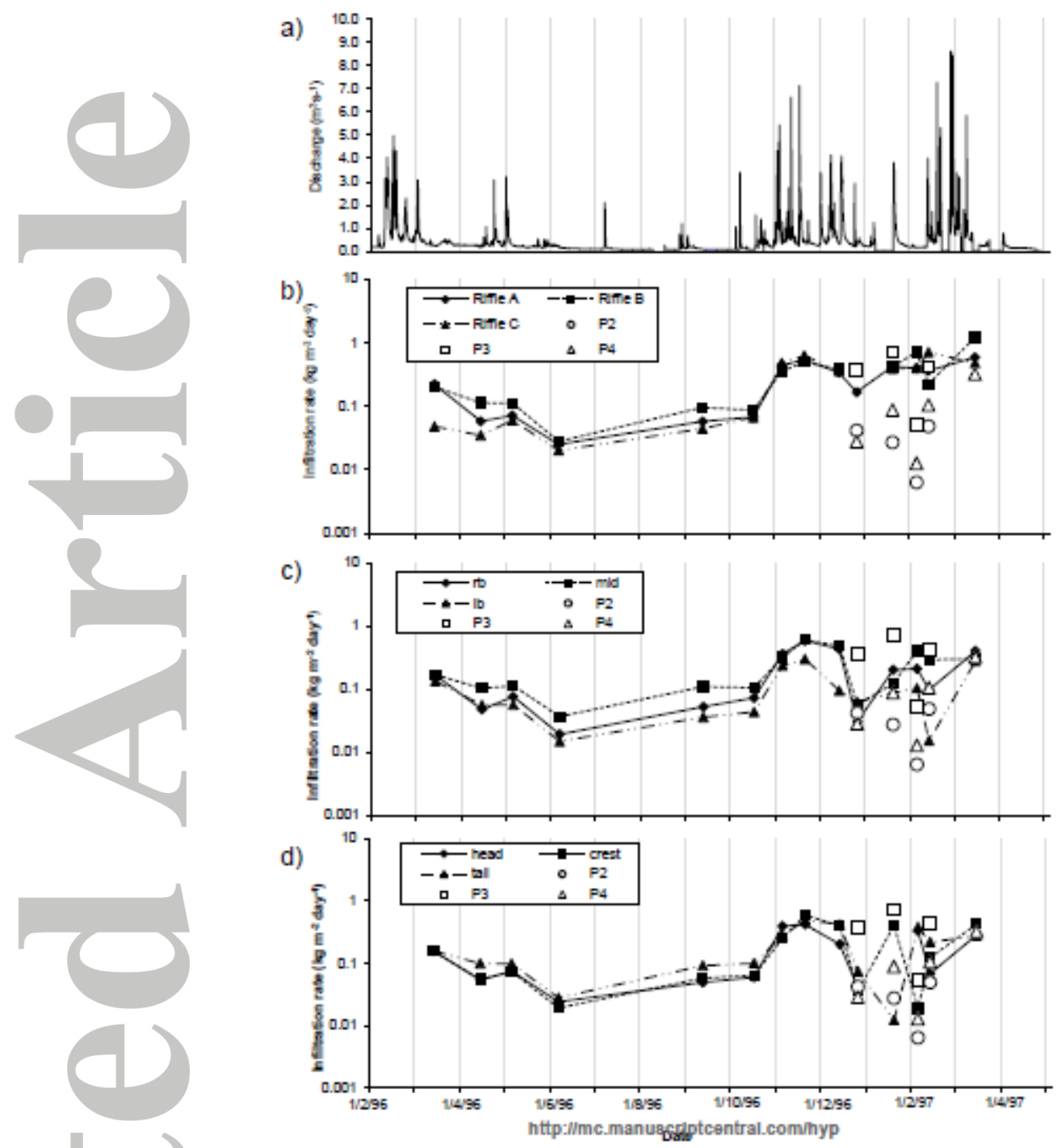

Figure 6 Temporal and spatial variability in infiltration rates, a) Discharge, b) between riffle, c) cross-channel variability using an ensemble of data from all the riffles, d) longitudinal variability using an ensemble of data from all the riffles. Rb- right-bank, lb- left-bank, midmid channel, $\mathrm{P}$ - pool. 


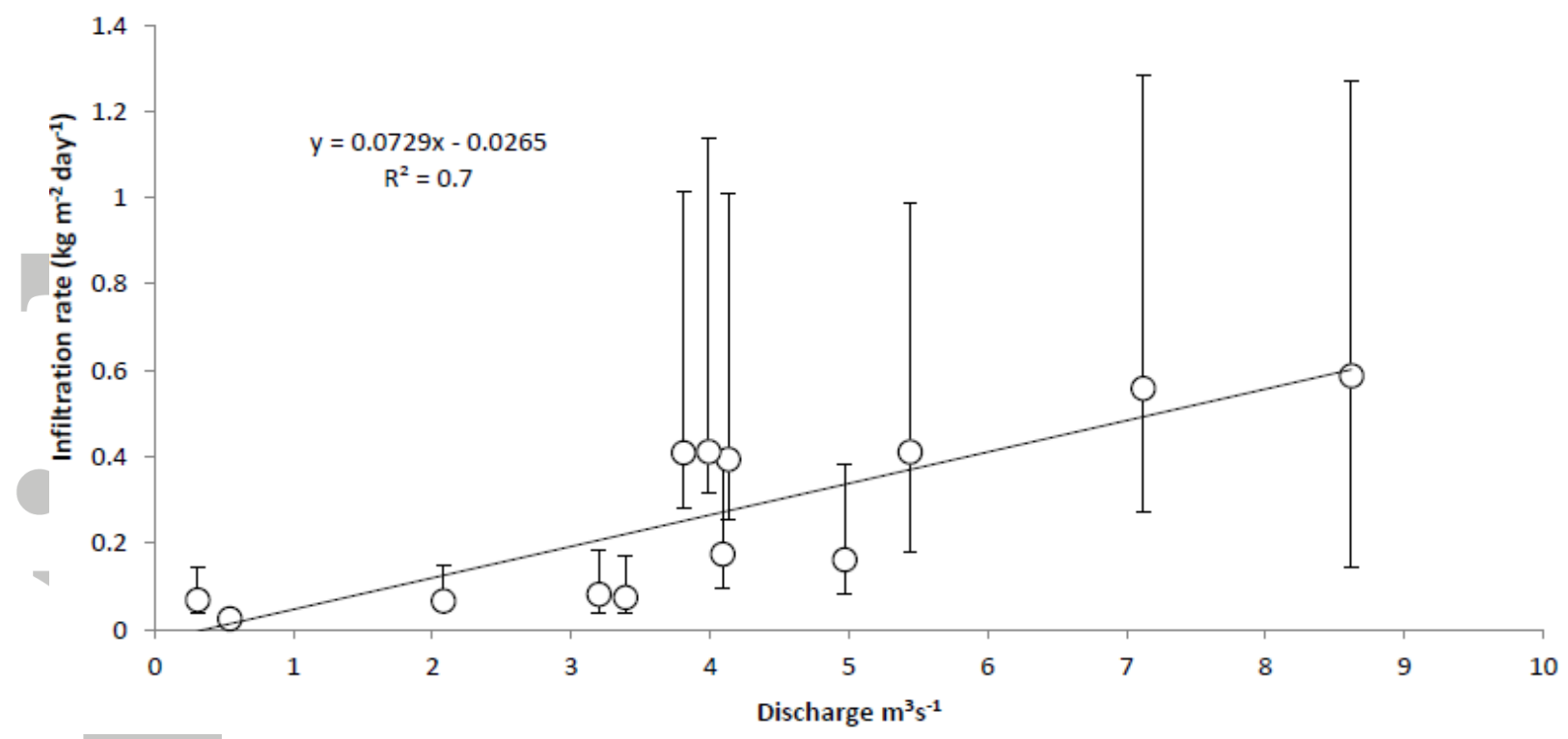

Figure 7 Relationship between mean infiltration rate and peak discharge. Error bars are $25^{\text {th }}$ and $75^{\text {th }}$ percentiles.

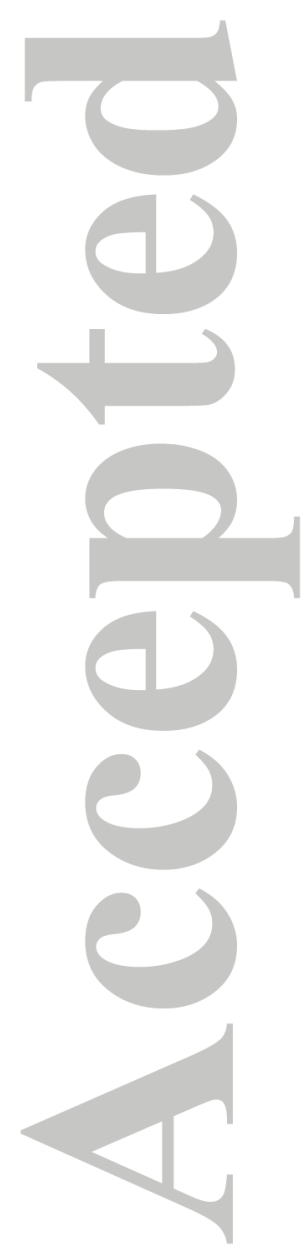




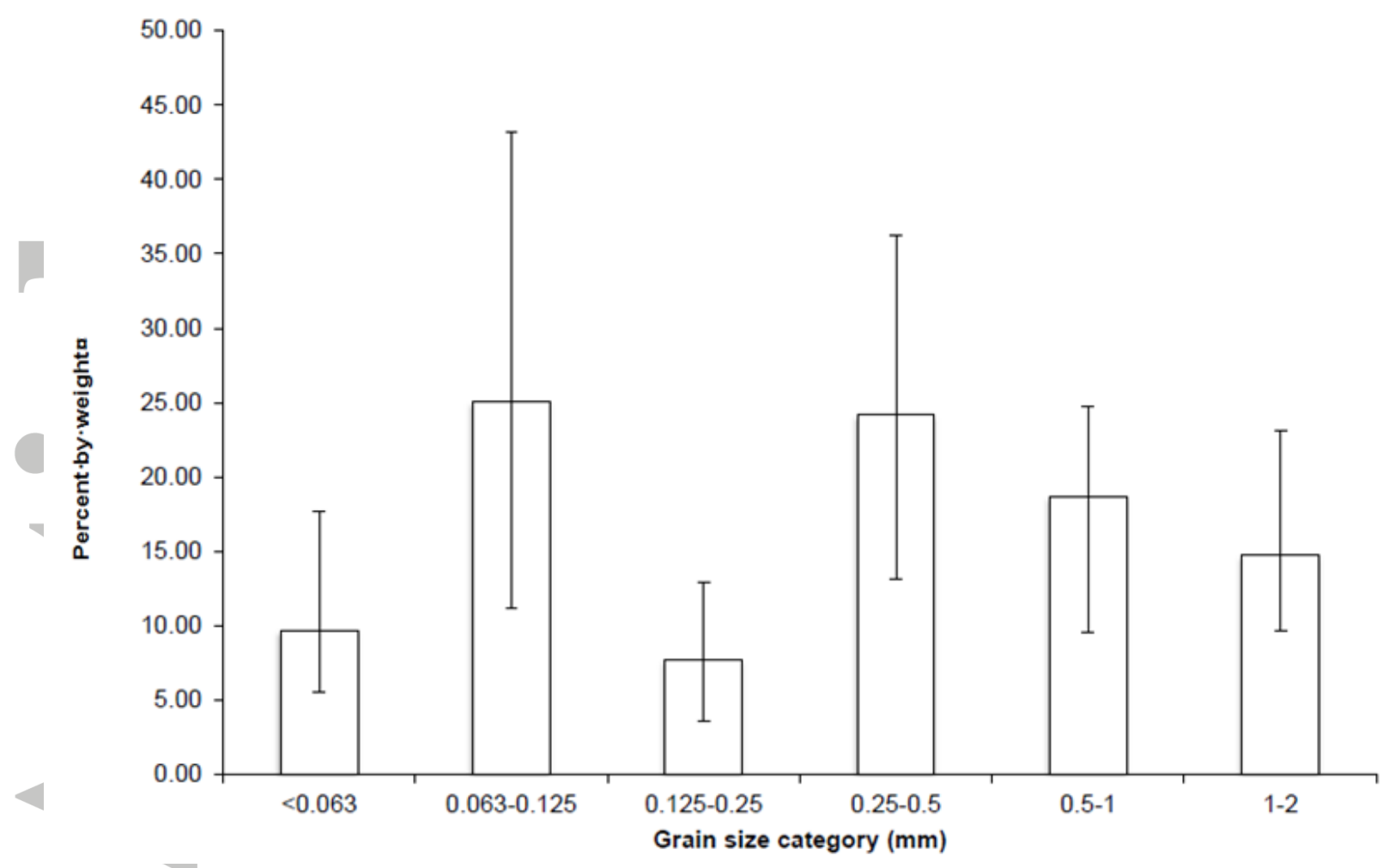

Figure 8 Grain size characteristics of infiltrating fines. Error bars show $5^{\text {th }}$ and $95^{\text {th }}$ percentiles.

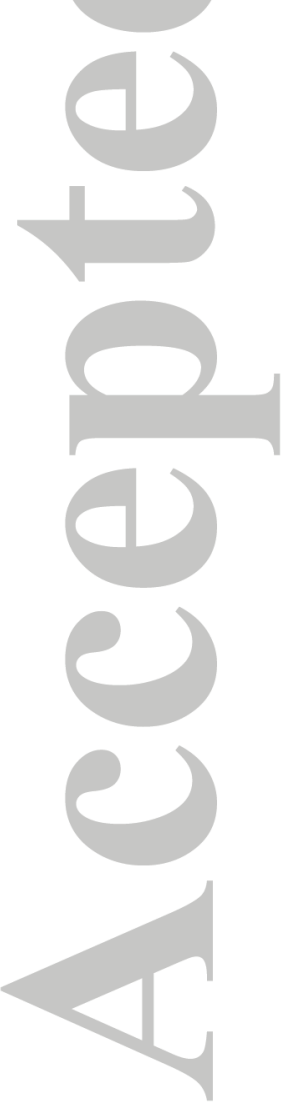



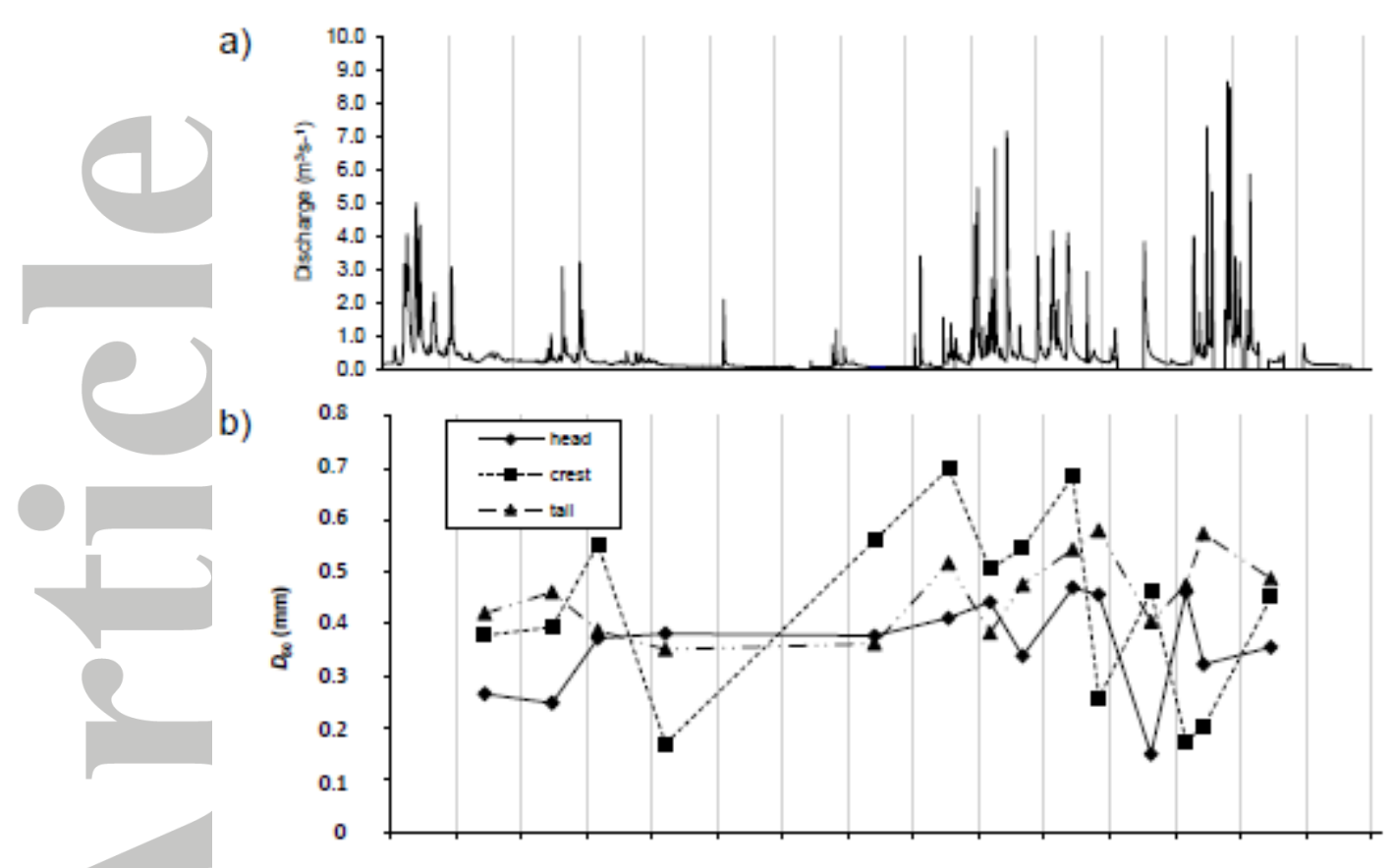

c)

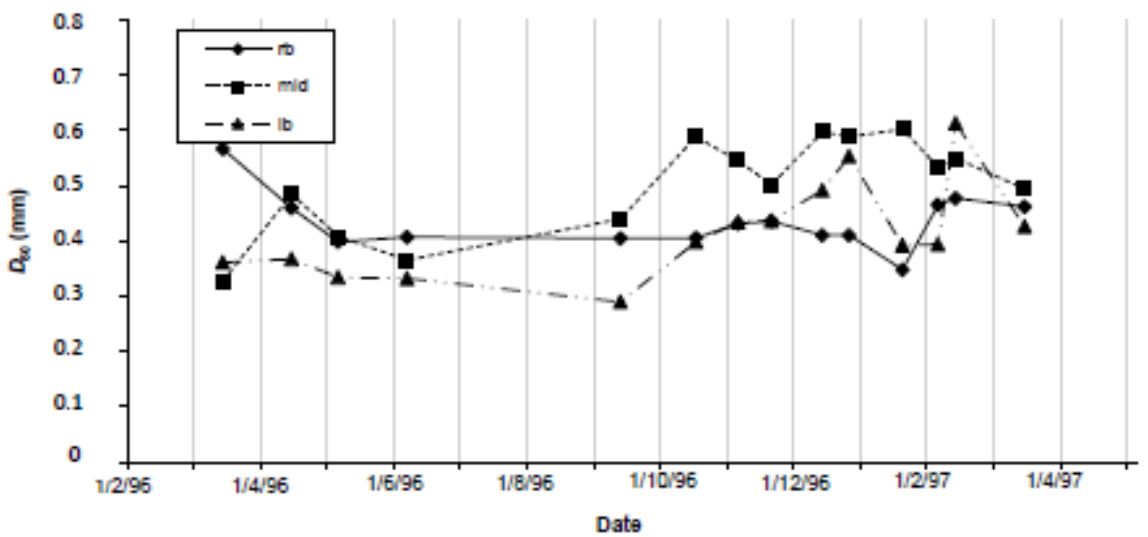

Figure 9 Temporal variations in median grain size characteristics for infiltrated sediments $(0.063-2 \mathrm{~mm})$ over the study period, a) discharge time series, b) Longitudinal variability for the head, crest and tail, c) Cross-channel variability $(\mathrm{Rb}$ - right-bank- looking downstream, $\mathrm{lb}$ - left-bank, mid-mid-channel) 


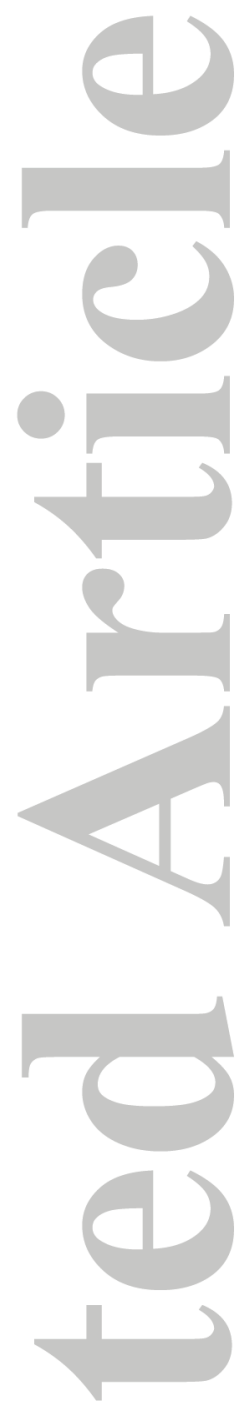

a)

b)

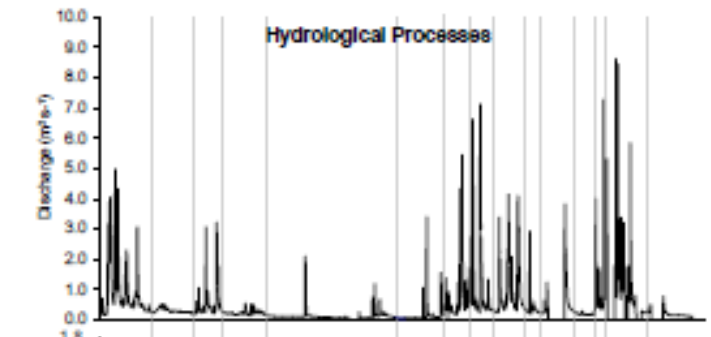

c)

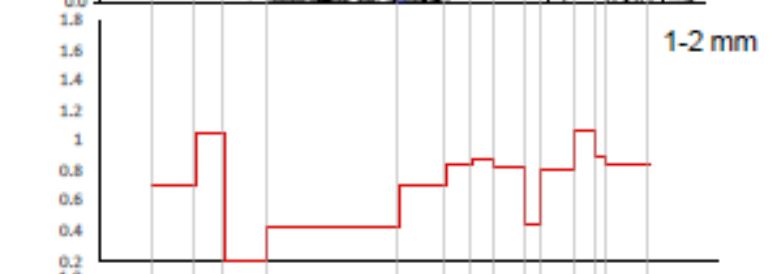

d)

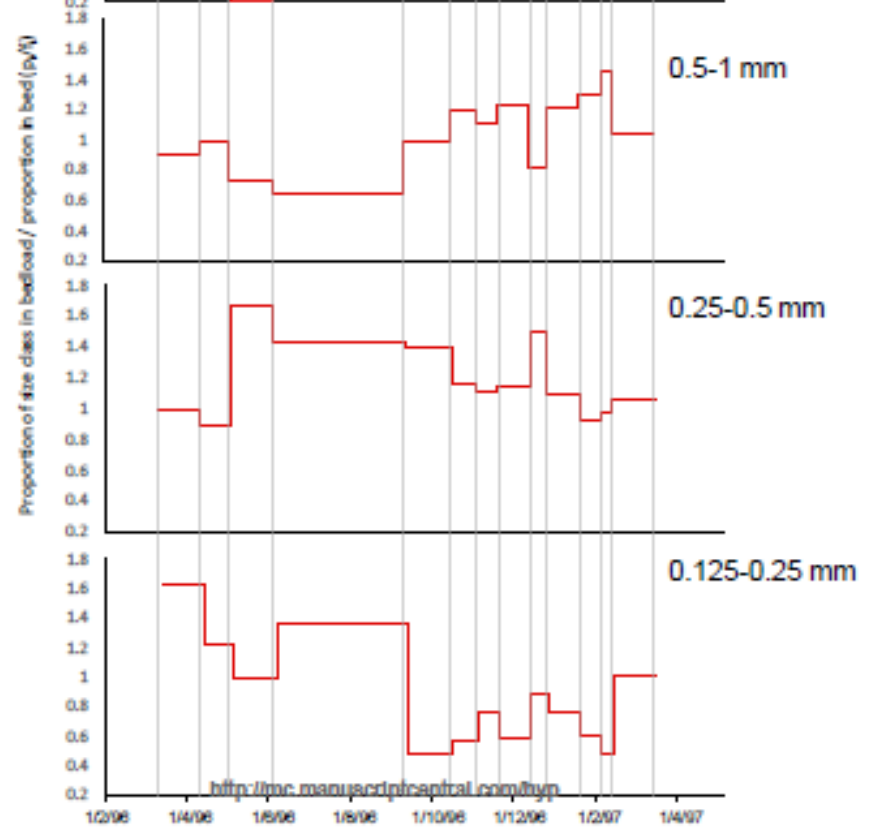

Figure 10 Temporal variations in proportions of different sand size fractions, relative to the proportions found in the substrate $\left(p_{i} / f_{i}\right)$, for the weighted average load for all traps located on riffle A. 

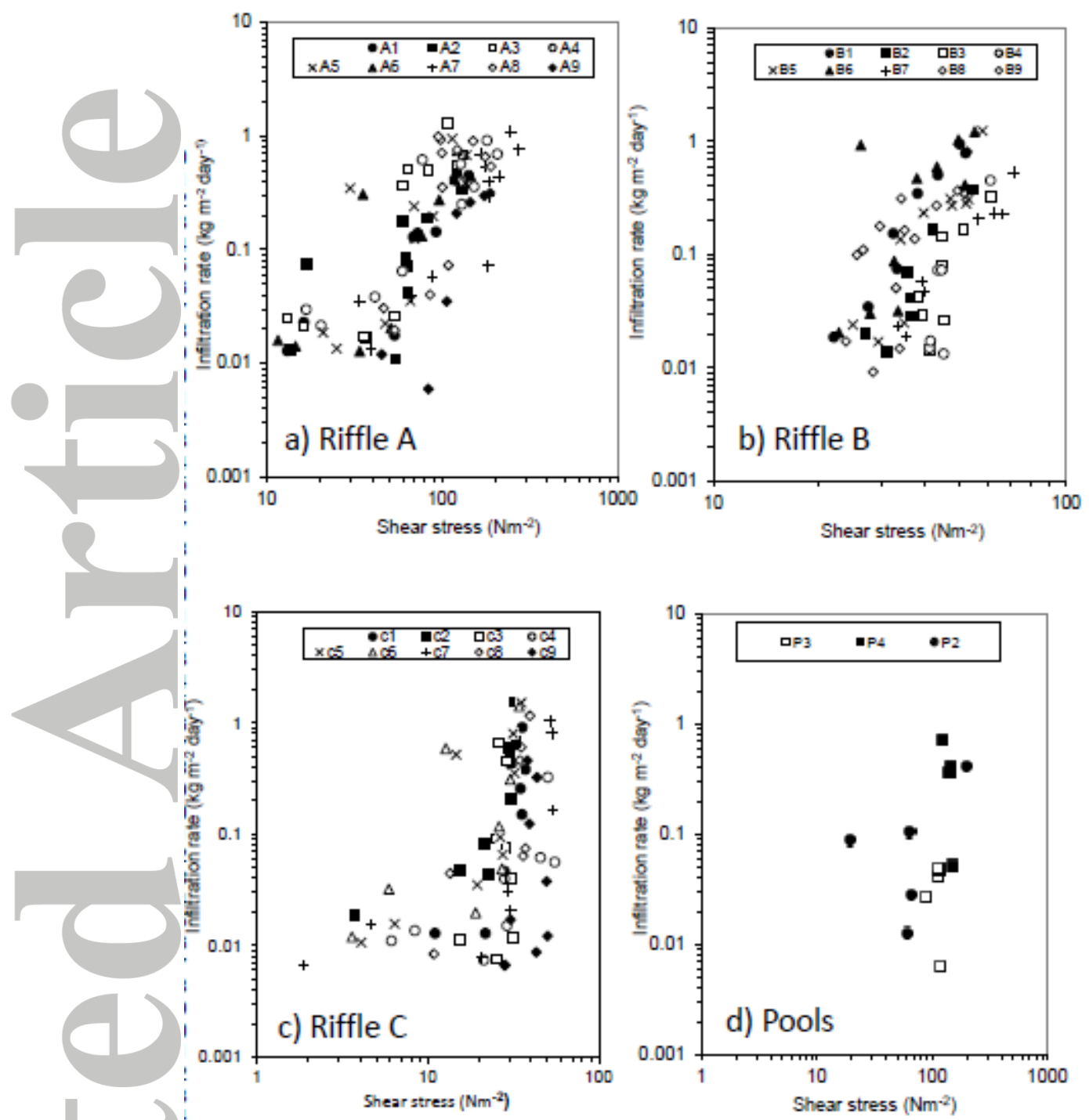

Figure 11 Relationship between boundary shear stress and infiltration rates for a) riffle A, b) riffle $\mathrm{B}$, and c) riffle $\mathrm{C}$. The position of cell numbers A1 to A9 are indicated in Figure 1c. 
a)

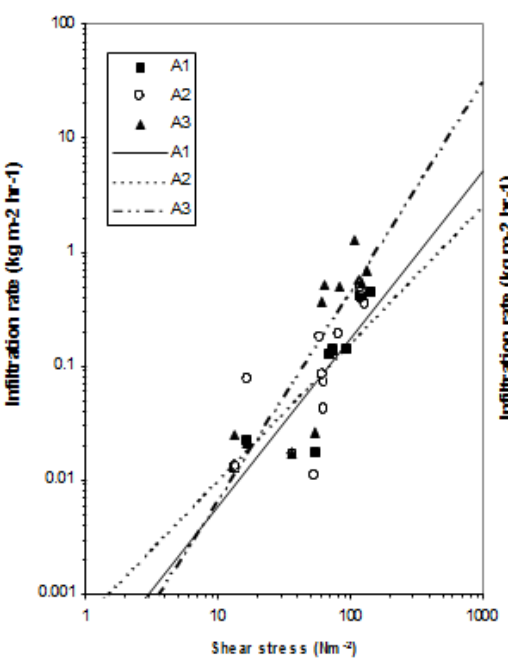

b)

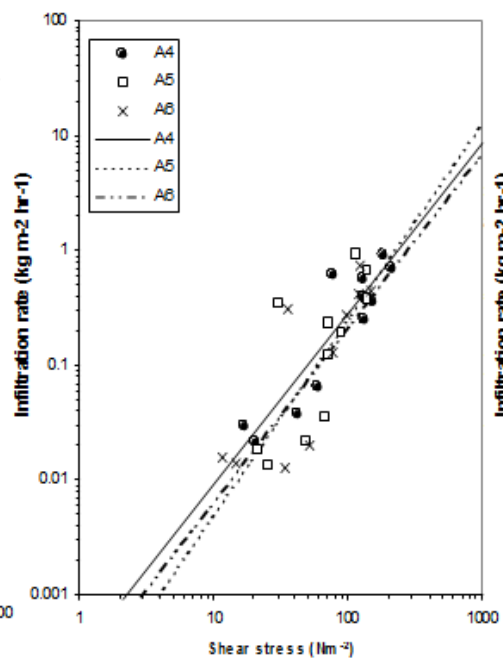

c)

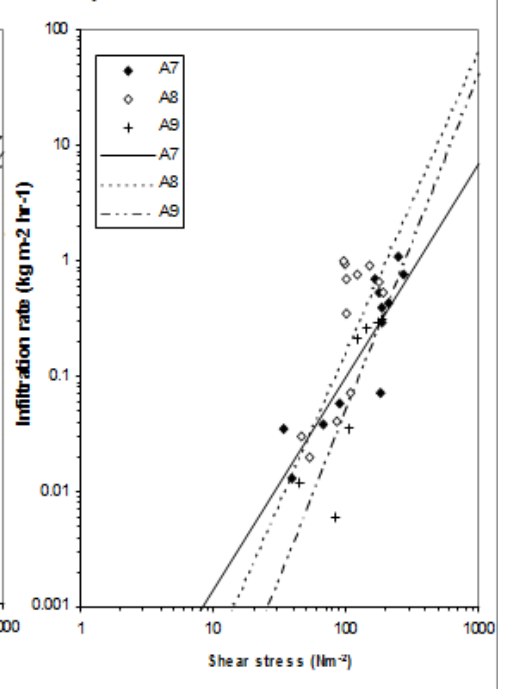

Figure 12 Relationship between shear stress and fine sediment $(<2 \mathrm{~mm})$ infiltration for Riffle A traps, a) riffle head traps, b) riffle crest traps, c) riffle tail traps. The position of cell numbers $\mathrm{A} 1$ to $\mathrm{A} 9$ are indicated in Figure $1 \mathrm{c}$.

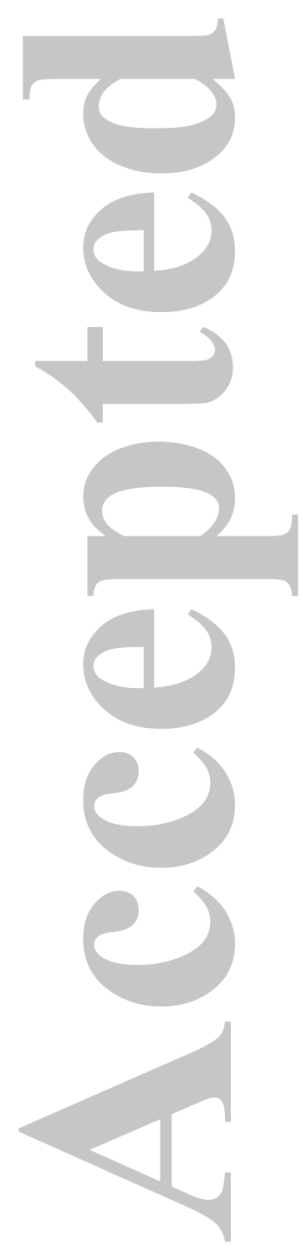




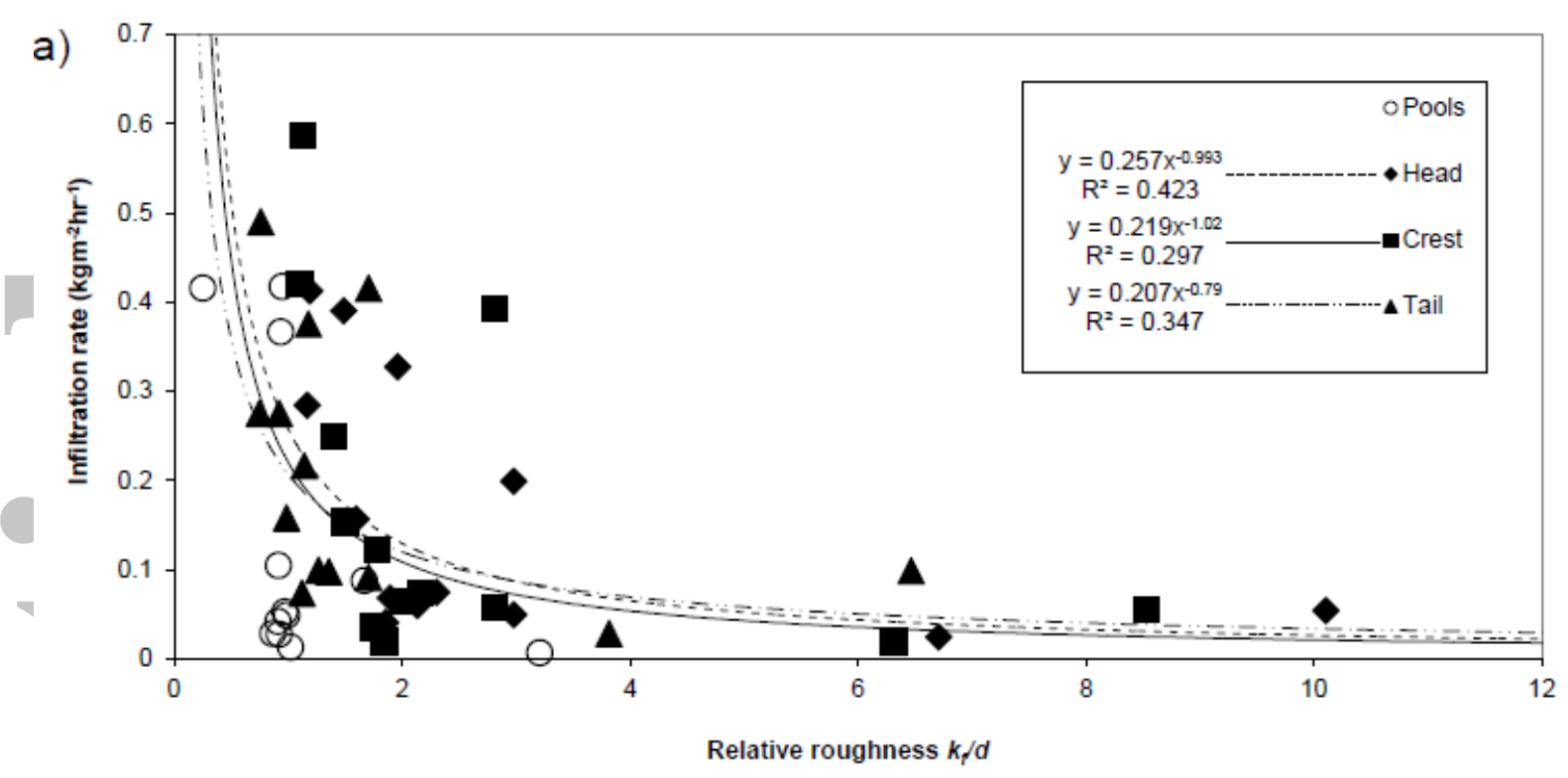

Figure 13 Relationship between fine sediment infiltration $(<2 \mathrm{~mm})$ and relative roughness $\left(k_{f} / d\right)$, a) down-riffle variation, b) cross-riffle variation. Pool data are also indicated.

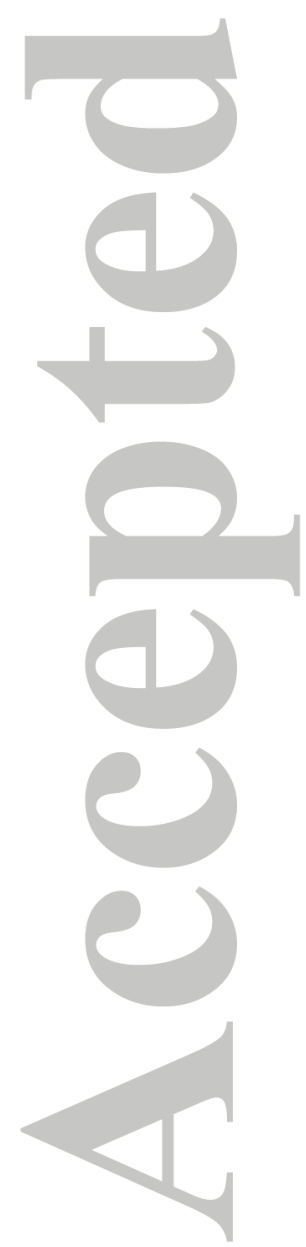

